\title{
Corporate governance, finance, and the real sector*
}

\author{
Paolo Fulghieri (UNC, CEPR and ECGI) and \\ Matti Suominen (Aalto University, Helsinki)
}

May 18, 2010

\footnotetext{
*For helpful comments, the authors would like to thank Philip Bond, Isil Erel, Michel Habib, Philipp Hartmann, Campbell Harvey, Florian Heider, Roman Inderst, Matthias Kahl, Yrjö Koskinen, Max Maksimovic, Holger Mueller, Marco Pagano, Gordon Phillips, Michael Roberts, Merih Sevilir, Andrei Schleifer, Raj Singh, and seminar participants at the Western Finance Association, the ASSA, and the European Finance Association meetings, the Banca d'Italia/CEPR Conference on Money, Banking and Finance, the Second Finance Summit, the Workshop on Politics of Corporate Governance at the Copenhagen Business School, the Corporate Governance conference in Washington University in St. Louis, New York University, University of Zurich, University of Houston, Wharton School, University of Maryland, Helsinki School of Economics, HKUST, National University of Singapore, Singapore Management University, and the Luxembourg School of Finance. Some of the results in this paper were contained in an earlier working paper entitled "Does bad corporate governance lead to too little competition?". All errors are only our own. E-mails: matti.suominen@hse.fi and Paolo_Fulghieri@unc.edu. Matti thanks OP-foundation and the Finnish Securities Markets Foundation for financial support.
} 


\title{
Corporate governance, finance, and the real sector
}

\begin{abstract}
This paper presents a theory of the linkages between corporate governance, corporate finance and the real sector of an economy. We examine a model of industry equilibrium with endogenous entry. We show that poor corporate governance and low investor protection generates less competitive economies, populated by firms with more insider ownership and greater leverage. The quality of the corporate governance system can also affect an economy's industrial structure: better corporate governance promotes the development of sectors more exposed to moral hazard, such as the high-technology industry. We also show that entrepreneurs may have a preference for "extreme" corporate governance systems, where the quality of corporate governance and the level of investor protection are either very high or very low. This suggests that entrepreneurs operating in economies endowed with a corporate governance system of low-quality may have little or no incentive to seek (or to lobby for) an improvement of the governance system of their economy. Finally we show that financial liberalizations facilitate firm entry and the adoption of more productive technologies, promoting economic growth. Our stylized model generates predictions that are consistent with several observed empirical regularities.
\end{abstract}




\section{Introduction}

What is the impact of corporate governance on the financial and industrial structure of an economy? Consider, for example, the case of Finland. During the past three decades the Finnish financial markets experienced a major shift from a bank-based financial system, similar to that in continental Europe and Japan, towards an Anglo-Saxon type financial system based primarily on securities markets. The stock market boomed, the banking sector consolidated and the ownership structure of companies changed dramatically, as domestic institutions divested their shareholdings, especially to foreign investors. ${ }^{1}$ In parallel, the industrial composition and financial structure of the economy also changed: earlier on, the Finnish economy was dominated by highly levered companies, mostly related to the heavy metal and forest industry, whereas today it is dominated by an equity financed high-tech sector. Hyytinen, Kuosa, and Takalo (2002) show that these shifts in corporate financing and the real sector followed a major change in the corporate governance regime of the country, and argue that the development of shareholder protection was a major driver in this reorganization. ${ }^{2}$

More generally, the quality of a country's corporate governance appears to be systematically related to the degree of competitiveness of its economy and its industrial and financial structure. ${ }^{3}$ In this paper, we present a theory of the linkages between corporate governance, corporate finance and the real sector of an economy. By using a parsimonious model, we study the relationships that emerge endogenously among the corporate governance system of an economy and its industrial and financial structure, and generate empirical predictions that are consistent with several observed stylized facts.

We examine a model of industry equilibrium where entry by firms into an industry is endoge-

\footnotetext{
${ }^{1}$ See, e.g., Hyytinen, Kuosa, and Takalo (2002) and Karhunen and Keloharhu (2001).

${ }^{2}$ An example of the shift in industrial composition is that in the year 2000 the Finnish firms filed domestically nearly twice as many patent applications as in 1980, at a per capita rate that was the second highest in the European Union. Today the country ranks as one of the most competitive and least corrupt countries in the world, according to the rankings from World Economic Forum, IMD and Transparency International.

${ }^{3}$ In Appendix I we provide empirical evidence showing that countries characterized by better corporate governance and investor protection have a more accessible local equity market, a higher degree of competition, and a more developed high-technology sector. In a similar spirit, Agrawal (2009) shows that product-market competition in a certain US state increases after passage in that state of Blue Sky laws, a statue aimed at investor protection at state level.
} 
nous. In our economy, firms (entrepreneurs) are endowed with technologies of different efficiency, with the more efficient ones requiring less capital. Entrepreneurs have limited wealth and seek financing in competitive capital markets. In the product market there is free-entry in that all entrepreneurs that obtain financing can enter. ${ }^{4}$ Thus, the degree of competition is endogenous, and is determined only by the ability of entrepreneurs to finance their firms.

The ability of entrepreneurs to find financing is limited by the presence of agency costs in both the debt and the equity markets. We model the agency cost of equity as in Stulz (1990, 2005), and assume that a firm's insiders may transform some of the cash-flow to equity (that is the firm's free cash flow, net of payments to creditors) as private benefits. The private use of the firm's resources is inefficient, making outside equity costly to the entrepreneur. We model the agency cost of debt as a risk-shifting problem (see Jensen and Meckling, 1976). As it is typical in the presence of moral hazard in the debt markets, firms must maintain a certain minimum level of equity to mitigate the moral hazard problem, generating debt capacity.

We show that corporate governance concerns in the equity market interact in an essential way with the moral hazard problem in the debt market, and jointly determine an economy's industrial and financial structure. When firm insiders have a greater ability to appropriate corporate resources (that is, when the agency costs of equity are more severe) debt becomes more desirable, since it reduces the need of outside equity financing. The ability to issue debt, however, is limited by the moral hazard problem in the corporate debt market. Thus, the simultaneous presence of the agency costs of debt and equity determines the overall ability of firms to raise capital, and limits entry into potentially profitable industries. Our model determines endogenously an economy's industry concentration and the financial structure of firms as a function of economywide factors, such as the overall quality of the corporate governance system, and sector-specific factors, such as an industry's exposure to moral hazard.

We show that economies characterized by worse corporate governance are characterized by greater industry concentration (in the spirit of Rajan and Zingales, 2003). ${ }^{5}$ In turn, greater

\footnotetext{
${ }^{4}$ The fact that financing is a major barrier to entry is reflected, e.g., in the OECD World Competitiveness Report 2006-2007, which lists availability of financing as one of the most important barriers affecting business competitiveness in several countries.

${ }^{5}$ Thus, the causality between the quality of an economy's corporate governance and its degree of competition may indeed run in the opposite way to the one suggested in traditional theory (see, for example, Alchian,
} 
industry concentration leads to greater industry profits, higher debt to equity ratios, more insider ownership, and higher returns on assets. These results are a direct consequence of endogeneity of industry concentration in our model: bad corporate governance reduces firms' ability to raise capital, which limits entry, increases industry profits and debt capacity, leading to greater leverage and insider ownership. Thus, by endogenizing industry concentration, our model establishes a novel link between the quality of the corporate governance system, ownership structure, industry concentration, and leverage. These predictions help to explain the stylized facts that emerge from cross countries studies such as La Porta, Lopez-de-Silanes, Shleifer and Vishny (1997) and (1998), Stulz (2005), among others.

We next show that corporate governance impacts also firms' choice of technology. This happens because bad corporate governance penalizes "equity intensive" technologies, i.e. industries where risk substitution is possible, such as the high-tech sectors. This means that in countries with poor corporate governance low-quality technologies may "crowd out," in equilibrium, highquality technologies that are more exposed to the moral hazard problem. Thus, countries with bad corporate governance systems may be "trapped" in an equilibrium in which their industries are dominated by less profitable and less efficient firms.

We extend our results in several directions. First, we introduce competitive banks that, at a cost, can reduce the extent of the moral hazard problem. In this way, entrepreneurs can obtain funds also in cases where they would not be able to raise capital from individual investors. We find that more efficient firms use direct financing, while marginal (less efficient) firms borrow from banks.

Second, we examine the benefits of convertible debt (and similar instruments produced by financial innovation) as tools to control moral hazard (as suggested in Green, 1984) and, thus, potentially facilitating entry. Surprisingly, we find that the agency costs of equity interact with the moral hazard problem in a way that convertible debt may in fact increase, rather than decrease, the insiders' incentives to take risks, thus with no effect on entry. This happens because insiders can benefit from conversion of convertible debt, since conversion (by eliminating debt) increases the cash flow to equity and allows more fund diversion, inducing more risk taking 1950, and Stigler, 1958): poor corporate governance and investor protection may in fact lead to high industry concentration. 
rather than discouraging it.

Third, we examine the incentives to improve the quality of the governance system both at firm level and for the overall economy. We show that firms in industries more exposed to moral hazard invest more to improve their corporate governance, generating a negative correlation between the quality a firm's governance system and its leverage. We then investigate entrepreneurs' preference for good governance and, thus, their incentives to lobby for good governance legislation in their economy.

We show that the quality of the corporate governance system has an ambiguous impact on entrepreneurs' welfare. On the one hand, entrepreneurs benefit from good governance because it reduces the cost of raising external equity; on the other hand, insiders are hurt by good governance, because it facilitates entry exposing them to more competition. We show that entrepreneurs may have a preference for "extreme" corporate governance regimes, that is for regimes with either a very high or a very low corporate governance quality. This observation suggests that entrepreneurs in economies characterized by bad corporate governance have little incentive to lobby for an improvement of their corporate governance system. It also suggests that countries would "segment" themselves into two groups, one with high-quality corporate governance systems, and one with low-quality systems, with little transition from one group to the other.

Finally, we consider the effect of financial market liberalizations on economic growth and firms' technology choices and preferences for governance. We show that financial market liberalizations, facilitating equity financing, induce more entry and the adoption of the more productive high-quality (equity-intensive) technologies, promoting economic growth. In addition, we show that liberalizations affect preferences for good governance and can make entrepreneurs more likely to benefit from improvements in the corporate governance system of their economies.

Our paper rests at the intersection of several strands of literature. The first one is the rapidly emerging literature on corporate governance and its effect on the real sector. ${ }^{6}$ By explicitly endogenizing the market structure of an industry, our paper shows that corporate governance and capital structure considerations interact in an essential way to determine the

\footnotetext{
${ }^{6}$ For excellent surveys of the literature, see Shleifer and Vishny (1997), La Porta, Lopez-de-Silanes, Shleifer and Vishny (2000), and Becht, Bolton, and Roell (2002).
} 
competitive conditions in the industry, in the spirit of Rajan and Zingales (2003). Closely related is also Stulz (2005), which argues that the agency cost of equity limits a firm's ability to raise capital and, therefore, to take advantage of the benefits of globalization, and John and Kedia (2003), who discuss the costs and benefits of alternative corporate governance systems. Our paper is also related to the growth and finance literature (see, for example, Rajan and Zingales, 1998, and Levine, 1997, for a comprehensive survey) in that better corporate governance can increase an economy's growth by facilitating firms' capital raising and the adoption of superior technologies. Thus, our paper provides a new channel through which financial liberalizations affect the real sector of an economy (see for example, Bekaert, Harvey, and Lundblatt, 2005, and 2009, for empirical evidence on the effect of financial liberalizations on economic growth and productivity).

The second strand of literature is the one on the interaction between financial and market structure (see e.g., Brander and Lewis, 1986, and Maksimovic, 1988, among others). These papers show that a firms's financial structure can be used strategically to induce a more aggressive behavior in the output market. In our paper, we rely on a different, non-strategic connection between market structure and firms' capital structure. In this sense, our paper is close to Maksimovic and Zechner (1991) and Williams (1995), which focus on the effects of agency costs on intra-industry variation of technology choice and capital structure. ${ }^{7}$ The third strand of literature is the one on industrial organization and the determinants of market structure (see, for example, Vives, 1999, among many others). Moreover, our paper extends in a (general) market equilibrium setting earlier literature that examines the impact of capital market imperfections on product market competition (see, for example, Poitevin, 1989, Bolton and Scharfstein, 1990, and Suominen, 2004).

Our paper is organized as follows. In section 2, we present our basic model. In section 3 we present the main results of the paper. In section 4 , we discuss our model's predictions. In section 5, we study the effect of corporate governance on the choice of technology. In section 6 , we examine the role of the banking sector and the role of financial innovation. In section 7 , we examine entrepreneurs' preferences for good governance. In section 8, we study the impact of financial liberalizations. Section 9 concludes the paper. All proofs are in Appendix II.

\footnotetext{
${ }^{7}$ See also Riordan (2003) for a discussion of this literature.
} 


\section{The basic model}

We examine an economy endowed with three types of agents: entrepreneurs, consumers and a large number of small investors. Entrepreneurs, with no initial wealth, are endowed with production technologies (described below). Production requires investment of capital, which entrepreneurs obtain from investors. Investors are endowed with one unit of cash each. Consumers purchase the goods produced by the entrepreneurs, and are characterized by their demand functions (described below). All agents are risk neutral.

Entrepreneurs, indexed by $i$, are distributed continuously over the real line, $i \in[0, \infty)$, and have access to two different production technologies. Technologies, indexed by $\tau \in\{H, L\}$, differ by their production costs and produce goods that can be of either "superior" or "inferior" quality. Goods of superior quality are valued more by customers and can be sold at a greater price. The high-quality technology, $\tau=H$, produces always superior quality goods, but at a greater cost. The low-quality technology, $\tau=L$, produces superior quality goods only with probability $\phi$, while with probability $1-\phi$ it produces goods of inferior quality. Production is subject to moral hazard in that an entrepreneur's choice of technology is unobservable to both investors and customers.

The total cost of producing $q_{i}$ units of output with technology $\tau$ by entrepreneur $i$ is

$$
C_{\tau, i}(q)=F_{\tau, i}+c q_{i}
$$

where $c$ is the (constant) marginal cost and $F_{\tau, i}$ the fixed cost, with $F_{H, i}>F_{L, i} \geq 0$. Thus, the high-quality technology has greater fixed cost. ${ }^{8}$ In addition, entrepreneurs differ by the efficiency of their technologies. We assume that more efficient entrepreneurs have technologies with lower fixed costs: $F_{\tau, i}=F_{\tau}+\theta i$, where $\theta$ is a measure of the efficiency differences among technologies. Thus, entrepreneurs with lower $i$ are more efficient.

If a firm has produced superior quality goods, it can sell its products to consumers in the output market, where the demand for its output, $x_{i}$, is

$$
x_{i}=\frac{\alpha}{n}-p_{i}+\widetilde{p}
$$

\footnotetext{
${ }^{8}$ We can interpret the greater fixed cost of high quality technologies as the additional R\&D expenditures required to produce goods with superior features, and thus of "superior" quality.
} 
where $\alpha$ is a positive constant that reflects the size of the market, $n$ is the total number of firms in the industry who produce superior quality goods, $p_{i}$ is firm $i$ 's price, and $\widetilde{p}$ the average price of the superior quality goods in the market. ${ }^{9}$ This means that if the $n$ most efficient firms produce superior quality goods, we have that $\tilde{p} \equiv \frac{1}{n} \int_{0}^{n} p_{j} d j$. As customary in the case of monopolistic competition, we assume that firms are small and therefore treat $n$ as a continuous variable (but we will still refer to $n$ as indicating the number of firms). Note that the demand schedule (2.2) is similar to that in monopolistic competition, where a firm takes the other firms' prices as given and acts as a monopolist on the residual demand curve. ${ }^{10}$

We assume that, if the firm's products are of inferior quality, consumers are willing to pay only the marginal cost $c$ for the goods, obliging the firm to set $p=c$. This implies that only firms that produce superior quality goods can recover their fixed costs. Furthermore, throughout the paper we assume that $\phi<F_{L} / F_{H}$, which implies that the high-quality technology is more efficient than the low-quality one. Thus, the parameter $\phi$ characterizes the severity of the moral hazard problem: a greater value of $\phi$ makes it more likely that a firm using the low-quality technology produces superior quality goods, increasing its incentive to select such technology. Since the value of the parameter $\phi$ depends on the technologies availability to firms, which are presumably similar to all firms in the same industry, we interpret $\phi$ as representing the exposure of a particular industry to moral hazard. We will initially assume that $\phi$ is sufficiently small (or $F_{L}$ sufficiently large) that the low-quality technology is not sustainable (i.e., profitable) in equilibrium:

Assumption A1: $\phi \leq \phi_{c}$ (where $\phi_{c}$ is defined in the Proof of Proposition 1, Appendix II).

This assumption guarantees that all entrepreneurs choose in equilibrium the high-quality technology. The case in which also the low-quality technology is profitable (and thus sustainable) to some firms is examined in Section 5.1.

Entrepreneurs obtain capital by issuing securities to investors. For simplicity, we restrict

\footnotetext{
${ }^{9}$ Note that the demand function $(2.2)$ implies that, when $p_{i}=\widetilde{p}$ (which will hold in a symmetric equilibrium) total industry demand, and thus output, is a constant and equal to $\alpha$. In Section 8 , we will examine the case in which total industry demand is a decreasing function of the average price $\widetilde{p}$ even when $p_{i}=\widetilde{p}$.

${ }^{10}$ See, for example, Fujita et al. (1999) and Ottavio et al. (2002). Our demand function is also similar to that in Salop (1979), with the difference that in his "circular city" model, $\widetilde{p}_{i}$ is the average price of the two firms located "closest" to $i$.
} 
the space of feasible contracts by assuming that firms can issue only debt and new equity. ${ }^{11}$ In particular, firm $i$ seeks to raise $F_{H, i}$ by selling to investors a fraction $\kappa_{i} \in[0,1]$ of its shares, valued at $S_{i}\left(\kappa_{i}\right)$, and zero coupon debt with a face value $B_{i}$ and a market value $D_{i}{ }^{12}$ Financial markets operate competitively, and all agents have access to a safe storage technology that offers zero return.

Outside investors are atomistic. After issuing equity, entrepreneurs maintain control of their firms, which they manage in their own interest. Entrepreneurial control of firms generates a conflict with outside shareholders who are exposed to (partial) wealth expropriation from the entrepreneur, who is the firm's insider. We abstract from other sources of disagreement between outside shareholders and insiders-managers (such as those due to differences in risk-aversion, as in John, Litov, and Yeung, 2007). In the spirit of Jensen (1986) and Shleifer and Wolfenson (2002) we model this "agency cost of equity" by assuming that entrepreneurs may divert to themselves a fraction $\beta$ of the residual cash flow of their firms, after debt is repaid. ${ }^{13}$ Thus, we can interpret the parameter $\beta$ as measuring the level of contractibility of the firm's cash-flow to equity and, in this way, representing the extent of the agency cost of equity. ${ }^{14}$

We assume that diversion of firm's cash flow is inefficient, and a unit of diverted cash flow is worth only $\mu<1$ to the entrepreneur (as in Pagano and Roell, 1998, Stulz, 2005, and Almeida and Wolfenzon, 2006). We interpret the parameters $\beta$ and $\mu$ as characterizing the quality of the corporate governance system and the level of investor protection of the economy in that they determine how efficiently entrepreneurs can divert their firms' cash flow into private

\footnotetext{
${ }^{11}$ We rule out the possibility of addressing the moral hazard problem by the use of optimal contracts. While we make this assumption for analytical tractability, our main results would hold as long as the moral hazard problem generates an industry-specific debt capacity, even after accounting for optimal contracting. This assumption is relaxed in Section 6.2, where we allow firms to address the risk-shifting problem by issuing convertible debt.

${ }^{12}$ Since, when A1 holds, the low-quality technology is not sustainable, entrepreneurs in equilibrium raise $F_{H, i}=S_{i}+D_{i}$ units of cash from investors to cover their fixed costs for the high-quality technology, $F_{H, i}$.

${ }^{13}$ This implies that debt is a hard claim in the spirit of Hart and Moore (1995) and (1998). This means that creditors rights are sufficiently strong to induce entrepreneurs to use all the available cash-flow to repay their creditors before engaging in any cash-flow diversion. Our results will continue to hold as long as creditor rights are stronger than shareholder rights.

${ }^{14}$ This means that, even if firm cash-flow is potentially observable by investors, only a fraction $1-\beta$ is contractible (see Hart and Moore, 1995, and Aghion and Tirole, 1992, where investors observe the state of the world, but have limited contractibility).
} 
benefits. ${ }^{15}$ For expositional simplicity, we assume that the fixed cost $F_{H}$ is sufficiently large that, in equilibrium, entrepreneurs equity retention is such that $1-\kappa_{i}<\mu$ for all $i$. This assumption implies that all entrepreneurs have an incentive to divert the fraction $\beta$ of the cash flow to equity. ${ }^{16}$

Assumption A2: $\mu \geq \mu_{c}$ (where $\mu_{c}$ is defined in the Proof of Proposition 1, Appendix II).

The timing of events is as follows. At $t=0$, entrepreneurs arrive to the capital market, announce the target amounts of funds that they wish to raise by issuing equity and debt with value $S_{i}$ and $D_{i}$, respectively, in order to raise from investors the amount $F_{H, i}=D_{i}+S_{i}$. Investors make financing offers to the entrepreneurs. The capital market closes when $n \geq 0$ firms have found financing, the investors expect to break even, no entrepreneur wishes to change its proposed financial structure and no additional firm can raise sufficient financing to enter.

At $t=1$, all $n \geq 0$ entrepreneurs that have been successful in raising $F_{H, i}$ of capital, $i \in[0, n]$, select their production technology, $\tau \in\{H, L\}$, and production takes place.

At $t=2$, entrepreneurs pay back or default on their loans. Entrepreneurs divert to themselves a fraction $\beta$ of the cash-flow that is left after lenders have been repaid. The residual fraction $1-\beta$ is distributed to shareholders. Investors and entrepreneurs consume their wealth.

An equilibrium in our model is characterized by the number of entrepreneurs entering the market, $n^{*}$, and their optimal strategies, $\left\{p_{i}^{*}, \tau_{i}^{*}, S_{i}^{*}, D_{i}^{*}, \kappa_{i}^{*}, B_{i}^{*}\right\}$, for $i \in\left[0, n^{*}\right]$, such that (a) the strategy of each entrepreneur maximizes his payoff given the strategies of the other players, (b) the goods markets clear, $q_{i}=x_{i}, \forall i$, and (c) the firms' capital structure and the number of entrepreneurs entering the market are such that no additional entry can occur with entrants earning non-negative profits.

\section{Equilibrium}

We solve the model by backward induction. In period $t=1$, entrepreneurs that have been successful in raising $F_{H, i}$ units of cash, choose their pricing strategy depending on whether they

\footnotetext{
${ }^{15}$ Evidence of large benefits of control and associated deadweight costs can be found in Albuquerque and Schroth (2008).

${ }^{16}$ If $1-\kappa_{i}<\mu$, some inframarginal entrepreneurs (the more efficient ones) would not, in equilibrium, divert resources for themselves. Allowing for this possibility would not affect our main results, however, because the properties of our equilibria depend only on the behavior of the marginal entrepreneurs, for which $\kappa_{i} \simeq 1$.
} 
have produced goods of superior or inferior quality. Taking as given the prices of the other firms producing superior quality goods, $\left\{p_{j}\right\}_{j \neq i}$, an entrepreneur with superior quality goods faces a residual demand curve (2.2) and maximizes his firm's total cash flow, $X_{i}^{T}$, by selecting

$$
p_{i}^{*} \in \arg \max _{p_{i}} X_{i}^{T}=\left(p_{i}-c\right)\left(\frac{\alpha}{n}-p_{i}+\widetilde{p}\right) .
$$

If, instead, the entrepreneur has produced inferior quality goods, he has no choice other than setting a price $p_{i}=c$, at which it can sell a fixed quantity, $\bar{x}$.

The total cash flow accruing to a firm depends on whether it has produced goods of superior or inferior quality, and therefore, on the choice of technology. Given the entrepreneurs' optimal pricing strategy, $p^{*}$, the total cash flow generated by firm $i, X_{i}^{T}$, is given by

$$
X_{i}^{T}\left(p^{*}, \tau_{i}\right)= \begin{cases}\left(p_{i}^{*}-c\right)\left(\frac{\alpha}{n}-p_{i}^{*}+\tilde{p}^{*}\right)+I_{\tau_{i}}\left(F_{H}-F_{L}\right) & \text { with pr. } 1-I_{\tau_{i}}(1-\phi) \\ I_{\tau_{i}}\left(F_{H}-F_{L}\right) & \text { with pr. } I_{\tau_{i}}(1-\phi),\end{cases}
$$

where $I_{\tau_{i}}$ is an indicator function that takes the value of one if $\tau_{i}=L$, and zero otherwise. Firm $i$ 's cash flow is divided between its creditors, $X_{i}^{D}\left(p^{*}, \tau_{i}\right)$, outside shareholders, $X_{i}^{S}\left(p^{*}, \tau_{i}\right)$, and the entrepreneur, $X_{i}^{E}\left(p^{*}, \tau_{i}\right)$, as follows

$$
\begin{aligned}
X_{i}^{D}\left(p^{*}, \tau_{i}\right) & \equiv \min \left\{B_{i} ; X_{i}^{T}\left(p^{*}, \tau_{i}\right)\right\} \\
X_{i}^{S}\left(p^{*}, \tau_{i}\right) & \equiv \kappa_{i}(1-\beta) \max \left\{X_{i}^{T}\left(p^{*}, \tau_{i}\right)-B_{i} ; 0\right\} \\
X_{i}^{E}\left(p^{*}, \tau_{i}\right) & \equiv\left[\mu \beta+\left(1-\kappa_{i}\right)(1-\beta)\right] \max \left\{X_{i}^{T}\left(p^{*}, \tau_{i}\right)-B_{i} ; 0\right\}
\end{aligned}
$$

Proceeding backward, at the beginning of period $t=1$, after having obtained financing, entrepreneurs choose their technology by maximizing their own expected payoff, selecting

$$
\tau_{i}^{*}\left(B_{i}\right) \in \arg \max _{\tau_{i} \in\{H, L\}} \mathbf{E}_{1} X_{i}^{E}\left(p^{*}, \tau_{i}\right)
$$

where $\mathbf{E}_{t}$ represents the expectation at $t$ on future cash flows. As it will become apparent below, the optimal choice of technology depends on the face value of the outstanding debt, $B_{i}$. The optimal financial structure is determined by entrepreneur $i$ at $t=0$ by maximizing

$$
\max _{S_{i}, D_{i}, \kappa_{i}, B_{i}} V_{i}=\mathbf{E}_{0} X_{i}^{E}\left(p^{*}, \tau_{i}^{*}\left(B_{i}\right)\right)
$$


subject to

$$
\begin{aligned}
S_{i} & \leq \mathbf{E}_{0} \kappa_{i}(1-\beta) \max \left\{X_{i}^{T}\left(p^{*}, \tau_{i}^{*}\left(B_{i}\right)\right)-B_{i} ; 0\right\}, \\
D_{i} & \leq \mathbf{E}_{0} \min \left\{B_{i} ; X_{i}^{T}\left(p^{*}, \tau_{i}^{*}\left(B_{i}\right)\right)\right\}, \\
S_{i}+D_{i} & =F_{H, i}
\end{aligned}
$$

where (3.8) and (3.9) are, respectively, the shareholders' and debt holders' participation constraints, (3.10) is the entrepreneur's financing constraint.

Proposition 1 (Equilibrium): The number of entrepreneurs that enter the market in equilibrium, $n^{*}$, and their choice of financing, $\left\{S_{i}^{*}, D_{i}^{*}\right\}_{i=0}^{n^{*}}$ is determined as follows:

1) In equilibrium, the first $n^{*}>0$ entrepreneurs enter the market, where $n^{*}$ is implicitly determined by

$$
n^{*}=\frac{\alpha}{\sqrt{F_{H}+\theta n^{*}+\eta \beta}},
$$

where $\eta \equiv \frac{\phi\left(F_{H}-F_{L}\right)}{1-\phi}$. All $i \leq n^{*}$ entrepreneurs choose the high-quality technology, and produce output, $q_{i}^{*}$, sold at a price, $p_{i}^{*}$, given by

$$
q_{i}^{*}=\frac{\alpha}{n^{*}}, p_{i}^{*}=c+\frac{\alpha}{n^{*}} .
$$

2) Entrepreneurs finance the fixed costs, $F_{H, i}$, by raising an amount of equity and debt equal to

$$
\begin{aligned}
S_{i}^{*} & =F_{H}+\theta i-D_{i}^{*}=(1-\beta) \eta-\theta\left(n^{*}-i\right), \\
D_{i}^{*} & =\bar{D} \equiv\left(\frac{\alpha}{n^{*}}\right)^{2}-\eta>0,
\end{aligned}
$$

and issue a fraction

$$
\kappa_{i}^{*}=1-\frac{\theta\left(n^{*}-i\right)}{(1-\beta) \eta}
$$

of their shares to outside investors. In equilibrium, the payoff to entrepreneur $i \in\left[0, n^{*}\right], V_{i}^{*}$, is

$$
V_{i}^{*}=\mu \beta \eta+\theta\left(n^{*}-i\right)
$$

Entry in the product market is determined by the interaction of imperfections in both the debt and the equity market, captured by the parameters $\beta$ and $\eta$, as follows. ${ }^{17}$ Absent capital

\footnotetext{
${ }^{17}$ Note that $\eta$ is strictly increasing in $\phi$, and hence also measures an industry's exposure to the moral hazard problem.
} 
market imperfections, that is, when $\beta=\eta=0$, entrepreneurs can raise in the capital markets all the funds necessary to finance profitable projects. In this case, entry will occur until the rents earned in equilibrium in the product market, which from (3.12) are given by $\left(\frac{\alpha}{n}\right)^{2}$, are equal to the fixed costs of the marginal entrant. This means that, absent capital market imperfections, the equilibrium number of entrepreneurs that enter the market, $n^{c}$, is determined by condition that the marginal entrepreneurs earn zero (expected) profits, that is, by

$$
\left(\frac{\alpha}{n^{c}}\right)^{2}-F_{H}-\theta n^{c}=0 .
$$

We refer to $n^{c}$ as the "perfectly competitive" outcome. From (3.11), it is easy to see $n^{c}>n^{*}$ whenever $\eta \beta>0$.

The presence of imperfections in the capital markets reduces entry because it limits the ability of entrepreneurs to raise capital on both the equity and the debt markets. Raising funds by issuing equity is costly because the entrepreneur appropriates a fraction $\beta$ of the residual cash flow, after the repayment of debt, and he enjoys only a fraction $\mu$ per dollar of diverted cash flow, while the remainder $1-\mu$ is dissipated. Since investors rationally anticipate the cash flow diversions, entrepreneurs ultimately bear the cost of this inefficiency, making outside equity expensive for the entrepreneurs. This dead-weight loss represents the agency cost of equity.

The presence of the agency costs of equity makes entrepreneurs to prefer to raise as much capital as possible in the debt market. The amount of funds that an entrepreneur can raise in the debt market, however, is limited by the moral hazard problem. By choosing low-quality technology (rather than the high-quality one) entrepreneurs save the amount $F_{H}-F_{L}$ in fixed costs but, with probability $\phi$, nevertheless obtain superior quality goods. Therefore the lowquality technology is riskier than the high-quality one, exposing creditors to a "risk shifting" problem. ${ }^{18}$ Since, given A1, the low-quality technology is not sustainable, entrepreneurs can in equilibrium select a capital structure whereby they have an incentive to choose the high-quality technology. Thus, the entrepreneur can only issue an amount of debt with face value $B_{i}^{*}$ that satisfies the incentive-compatibility condition

$$
\left(\frac{\alpha}{n^{*}}\right)^{2}-B_{i}^{*} \geq \phi\left[\left(\frac{\alpha}{n^{*}}\right)^{2}-B_{i}^{*}+F_{H}-F_{L}\right] .
$$

\footnotetext{
${ }^{18}$ Our results will hold also in the case that the high quality technology produces low quality goods with some small but positive probability.
} 
This implies that

$$
D_{i}^{*}=B_{i}^{*} \leq \bar{D} \equiv\left(\frac{\alpha}{n^{*}}\right)^{2}-\eta,
$$

where $\bar{D}$ represents the firm's debt capacity. Note that $\eta$ (defined in Proposition 1) represents the minimum equity value that a firm must maintain to ensure that the high-quality technology is optimally chosen, and it depends on the severity of the moral hazard problem.

Debt capacity $\bar{D}$ is industry specific and depends both on the extent of the moral hazard problem and on the level of industry concentration, $n^{*}$. Greater exposure to moral hazard increases the minimum equity that a firm must maintain to induce insiders to choose the highquality technology, reducing debt capacity. Conversely, greater industry concentration raises a firm's economic profits, increasing its value and, thus, debt capacity. ${ }^{19}$

In equilibrium, entrepreneurs issue debt up to debt capacity, $\bar{D}$, and then sell equity to outside investors until $\kappa_{i}=1$, for the last entrant (i.e., the marginal entrepreneur). Given that $\eta$ represents the minimum equity that all firms must maintain to satisfy the incentivecompatibility condition (3.18), and that the entrepreneur appropriates a fraction $\beta$ of it, the amount of equity that the marginal entrepreneur, $n^{*}$, issues is $S_{n^{*}}^{*}=(1-\beta) \eta$. Thus, the marginal entrepreneur that can obtain financing, $n^{*}$, is determined by

$$
\bar{D}+S_{n^{*}}^{*}=\left(\frac{\alpha}{n^{*}}\right)^{2}-\beta \eta=F_{H, n^{*}}=F_{H}+\theta n^{*} .
$$

This condition requires that, for the marginal entrepreneur, the total value of the firm's cash flow, $\left(\frac{\alpha}{n^{*}}\right)^{2}$, after the diversion to the entrepreneur, $\beta \eta$, is equal to its fixed costs, $F_{H, n^{*}}$. Inframarginal entrepreneurs issue to outside shareholders only the amount of equity that is strictly necessary to raise $F_{H, i}$, leading to (3.13). Since firms' equity has a market value $E^{M *} \equiv(1-\beta) \eta$, the fraction of equity sold by entrepreneur $i$ is $S_{i}^{*} / E^{M *}$, giving (3.15). In equilibrium, the marginal entrepreneur earns an economic profit which is equal to the value of the cash flow diversions, $\mu \beta \eta$. Inframarginal entrepreneurs benefit from their greater efficiency by issuing less equity, and

\footnotetext{
${ }^{19}$ Note that in our stylized model debt capacity is the same for all firms in the same industry since, from the incentive compatibility conditions, the potential gain from deviating to low quality technology, $F_{H}-F_{L}$, is independent of $i$. This assumption can be easily relaxed by assuming, for example, that more efficient firms have also lower variable costs, which would lead to greater debt capacity. Our main results will hold as long as there is a systematic difference in debt capacity across industries which is driven by heterogeneity in production technologies.
} 
thus by earning, in equilibrium, greater economic profit, given by (3.16).

Finally, from (3.14), it is easy to see that, absent moral hazard (that is, with $\eta=0$ ), all firms would be entirely debt financed and entry would occur until $n^{*}=n^{c}$. Similarly, absent the agency cost of equity (that is, with $\beta=0$ ) all firms would have costless access to equity and again, from (3.20), entry would occur until $n^{*}=n^{c}$. It is precisely the interaction of the imperfections in both the equity and debt markets, i.e. when $\beta \eta>0$, that limits the ability of entrepreneurs to raise capital, reducing the equilibrium number of firms that can enter a new market.

\section{Corporate Governance, Finance, and Industry Concentration}

Our model shows that industry concentration and firm financial and ownership structures are jointly determined by the interaction of the quality of the corporate governance system of an economy (measured by $\beta$ ) and industry characteristics (that is, the exposure to the moral hazard problem, measured by $\eta$ ). In this section we develop predictions on the cross sectional variation that would be observed across industries within an economy (that is, in the same legal jurisdiction), and across different countries with heterogenous legal jurisdictions.

Proposition 2 (Corporate governance, industry concentration and financial structure): Economies with worse corporate governance regimes are characterized by greater industry concentration, greater debt level, lower book and market value of equity and, for the more efficient entrepreneurs, by greater insider ownership (defined by $\omega_{i} \equiv 1-\kappa_{i}$ ):

$$
\frac{\partial n^{*}}{\partial \beta}<0, \quad \frac{\partial \bar{D}}{\partial \beta}>0, \quad \frac{\partial S_{i}^{*}}{\partial \beta}<0, \quad \frac{\partial E_{i}^{M *}}{\partial \beta}<0, \frac{\partial \omega_{i}^{*}}{\partial \beta}>0 \text { iff } i<i_{c}(\beta, \eta),
$$

where $i_{c}(\beta, \eta)$ is defined in the Appendix. Furthermore, defining the elasticity of entry to corporate governance as $\varepsilon\left(n^{*}, \beta \mid \eta\right)=\left|\frac{\partial n^{*}}{\partial \beta} \frac{\beta}{n^{*}}\right|$, we have that

$$
\frac{\partial \varepsilon\left(n^{*}, \beta \mid \eta\right)}{\partial \eta}>0
$$

Proposition 2 shows that the quality of corporate governance and investor protection affect several critical features of the industrial and financial structure of an economy. First, economies characterized by worse corporate governance (higher $\beta$ ) have greater industry concentration 
(lower $n^{*}$ ). This happens because worse corporate governance regimes limit entrepreneurs' ability to raise equity from capital markets, which impairs entry of new firms and, thus, increases industry concentration. In addition, from (4.2), the elasticity of the number of firm entering an industry in equilibrium, $n^{*}$, is increasing in that industry's exposure to the moral hazard problem, $\eta$. This means that the effect of the quality of the corporate governance system on entry is more pronounced precisely in those sectors where equity financing is more critical.

Second, interestingly, low-quality corporate governance regimes lead to greater debt capacity. This property is a direct consequence of the endogeneity of industry concentration: A worse corporate governance regime, reducing entry, leads to greater industry concentration and, therefore, to greater firms' profits in equilibrium. In turn, greater profits relax the incentive compatibility constraint, (3.18), and increase debt capacity.

Third, worse corporate governance, increasing insiders' cash flow diversions, reduces the cash flow that can be pledged to outside investors and, thus, leads to lower book and the market values of equity (given by $S_{i}^{*}$ and $E_{i}^{M *}$, respectively). The effect of the quality of corporate governance on insider ownership, $\omega_{i}^{*}$, depends on a firm's position within an industry. Less efficient firms (greater $i$ ) rely relatively more on equity financing. Worse corporate governance implies that these firms must sell a relatively greater fraction of equity to outsiders, decreasing insider ownership. Conversely, more efficient firms, $i<i_{c}$, sell less equity and, thus, rely relatively more on debt financing. This means that the increase in debt capacity that comes with a worse corporate governance regime (as discussed above) allows these firms to issue relatively less equity to outside investors, increasing insider ownership.

Proposition 3 (Moral hazard, industry concentration, and financial structure): Sectors exposed to more severe agency costs of debt are characterized by greater industry concentration, lower corporate debt level, greater book and market value of equity, and less insider ownership:

$$
\frac{\partial n^{*}}{\partial \eta}<0, \quad \frac{\partial \bar{D}}{\partial \eta}<0, \quad \frac{\partial S_{i}^{*}}{\partial \eta}>0, \quad \frac{\partial E_{i}^{M *}}{\partial \eta}>0, \quad \frac{\partial \omega_{i}^{*}}{\partial \eta}<0 .
$$

Industries exposed to a more severe moral hazard problem (greater $\eta$ ) are characterized by greater concentration. This happens because greater exposure to moral hazard reduces a firm's debt capacity. Firms, however, can only partially offset the reduction in debt financing with a corresponding increase in equity. This happens because a reduction of a dollar in cash 
flow paid out to creditors results only in $1-\beta$ dollars of added "equity capacity" (since a fraction $\beta$ of the firm's cash flow is diverted by the entrepreneur). Therefore, worse moral hazard impairs firms' overall ability to raise funds, leading to less entry and greater industry concentration. Furthermore, entrepreneurs in equilibrium substitute debt financing with equity financing, leading to greater book and market value of equity and less insider ownership.

Propositions 1 - 3 generate predictions on the cross sectional variation that would be observed within a country (that is, within the same legal jurisdiction), and across countries (that is, in legal jurisdictions that have potentially different corporate governance and investor protection regimes). ${ }^{20}$ We consider the effect of the three parameters $\{i, \eta, \beta\}$ on several key ratios determined endogenously in the model. First, within an industry, for each individual firm $i \in\left[0, n^{*}\right]$ we consider the debt-to-equity ratio, $D_{i}^{*} / S_{i}^{*}$; the book-to-market ratio of equity $S_{i}^{*} / E_{i}^{M *}$; the degree of insider ownership, $\omega_{i}^{*}=1-\kappa_{i}^{*}$; and the return on assets: $R O A_{i}^{*}=X_{i}^{*} / F_{H, i}$. Second, we compare these same key across industries and legal jurisdictions. ${ }^{21}$ Tables 1-a and 1-b below present the sign of the partial derivatives of the ratios with respect to the relevant parameters. ${ }^{22}$

By contrasting tables 1-a and 1-b, it is easy to see that the correlation between leverage and firm profitability within an economy can differ when measured within the same industry or across industries. In our model, firms in the same sector differ only by the efficiency of their technology, while firms in different sectors of an economy differ also by the severity of the moral hazard problem and, therefore, by their debt capacity. Within a given sector, more efficient firms require less capital and need to issue less equity than more inefficient ones. Thus, more efficient firms, have greater return on assets and issue relatively less equity, generating a positive relationship between leverage and profitability. ${ }^{23}$ Interestingly, this result is consistent with the

\footnotetext{
${ }^{20}$ Note that in our model, firms' heterogeneity originates from three different sources. First, within a given industry, firms differ by their level of efficiency $i$, with more efficient firms needing less capital. Second, across industries in the same economy, different sectors have different exposure to the moral hazard problem, and thus different values of $\eta$. Third, across countries, different economies are characterized by different quality of their corporate governance system, and therefore have different values of $\beta$.

${ }^{21}$ For tractability, we consider the aggregate ratios for the industry, rather than the averages of the ratios for all firms in the industry.

${ }^{22}$ The proofs are omitted, but they are available from the authors upon request.

${ }^{23}$ Note also that this result is robust to alternative specifications of the source of heterogeneity within an industry. For example, firms in the same industry may require the same fixed assets, $F_{H}$, but may differ by the marginal costs, $c_{i}=c+\theta i$. Even in this case, more profitable firms would have greater debt capacity, generating
} 
finding in Mackay and Phillips (2005) that, within industries, new entrants (corresponding to our marginal firms) have less leverage and are less profitable than incumbent firms.

The relationship between profitability and leverage is reversed when we compare across sectors. Firms in sectors more exposed to moral hazard have lower debt capacity and leverage. In addition, these industries are more concentrated and, therefore, are associated with greater profits and return on assets. Thus, greater exposure to moral hazard leads at the same time to less levered, more profitable firms and to greater industry concentration, generating a negative relationship between leverage and profitability, and between leverage and industry concentration.

Table 1-a: Within industry cross-sectional variations

\begin{tabular}{|c|c|c|c|c|}
\hline & $\frac{D_{i}^{*}}{S_{i}^{*}}$ & $\frac{S_{i}^{*}}{E_{i}^{M *}}$ & $\omega_{i}^{*}$ & $R O A_{i}^{*}$ \\
\hline$i$ & - & + & - & - \\
\hline
\end{tabular}

1-b: Cross sectional variation across industries and legal jurisdictions

\begin{tabular}{|c|c|c|c|c|c|}
\hline & $\left(\frac{D^{*}}{S^{*}}\right)^{i n d .}$ & $\left(\frac{S^{*}}{E^{M *}}\right)^{i n d .}$ & $\left(\omega^{*}\right)^{i n d}$ & $\left(R O A^{*}\right)^{i n d}$ & $n^{*}$ \\
\hline$\eta$ & - & + & - & + & - \\
\hline$\beta$ & + & - & + & + & - \\
\hline
\end{tabular}

A plus (negative) sign indicates a positive (negative) partial derivative of the ratio or variable with respect to $i, \eta$ or $\beta$, respectively. Parameter $i$ represents firm efficiency, with a greater $i$ corresponding to a less efficient firm; parameter $\eta$ represents a technology's exposure to moral hazard, with a greater $\eta$ corresponding to greater moral hazard; parameter $\beta$ represents the quality of a country's corporate governance framework, with a greater $\beta$ corresponding to a lower level of investor protection and corporate governance quality.

The negative correlation between leverage and profitability is a direct consequence of the endogeneity of industry concentration of our model. This implies that a static trade-off model of the determination of a firm's capital structure (such as the one discussed here) can generate a negative correlation between leverage and profitability. This result depends crucially on the again a positive correlation between leverage and profitability. 
negative correlation between debt capacity and profitability that is generated by endogenous entry. ${ }^{24}$

Across economies, our model predicts that economies characterized by worse corporate governance systems (that is, by higher $\beta$ ) are also characterized by greater industry concentration, higher debt to equity ratios (when equity is measured either at book or market value), greater insiders' ownership, and greater returns on assets. These results are again the direct consequence of the endogeneity of industry concentration and debt capacity: worse corporate governance regimes reduce a firm's ability to raise capital, which limits entry and, in turn, leads to greater debt capacity (and, leverage) and greater insider's ownership. Thus, by endogenizing industry concentration, our model establishes a novel link between the quality of the corporate governance system, ownership structure, industry concentration, and leverage.

These results are consistent with several the stylized facts that emerge from cross countries studies. For example, La Porta, Lopez-de-Silanes, Shleifer and Vishny (1997 and 1998) find that countries with worse corporate governance have more debt relative to equity financing, lower market values of firms (compared to GDP), and larger ownership by insiders. More recently, Stulz (2005) finds that countries with worse corporate governance are characterized by a smaller fraction of widely held firms and, thus, greater insiders' ownership. Demirguc-Kunt and Maksimovic (1998) and Hail and Leuz (2006) find that countries endowed with a better legal environment are characterized by a lower return on capital. Klapper, Laeven and Rajan (2004) documents the beneficial effect of regulation, that is aimed at a better development of financial markets, on the entry of new firms, especially in industries with high R\&D intensity or industries that have greater capital needs. ${ }^{25}$

A further implication of our paper is that the quality of the corporate governance system of an economy has an independent impact on the financial structure choices of firms, beyond

\footnotetext{
${ }^{24}$ In this way, our model helps explaining the apparent puzzle given by the negative relationship between profitability and leverage that is documented in several empirical studies such as Titman and Wessels (1988), Rajan and Zingales (1995), Fama and French (2002), Demirguc-Kunt and Maksimovic (1988), and Booth, Aivazian, Demirguc-Kunt, and Maksimovic (2001) among others.

${ }^{25}$ In a similar vein, Fan, Titman and Twite (2003) documents a negative correlation between leverage and the strength of a country's legal system. The paper also shows that the presence of high-quality auditors (as measured by the market share of the Big-five accounting firms) is negatively related to leverage, especially in developing countries.
} 
firm-specific characteristics. Thus our model provides an explanation for the findings of Booth, Aivazian, Demirguc-Kunt, and Maksimovic (2001), which shows that country specific factors (such as its legal framework) are as important as firm-specific factors in determining a firm's capital structure decision.

\section{Governance and Technology Choice}

The quality of the corporate governance system affects also firms' choice of technology and thus, through this second channel, the industrial structure of an economy. We investigate this possibility in this section by considering the parameter region where Assumption A1 does not hold, so that the low-quality technology is potentially profitable. We maintain the assumption that the high-quality technology is more efficient that the low-quality one.

Proposition 4 (Corporate governance and technology choice): Let $\phi \in\left(\phi_{c}, F_{L} / F_{H}\right)$ and $\beta<\bar{\beta}$ (where $\bar{\beta}>0$ is defined Appendix II). In equilibrium $n^{\prime}>n^{*}$ entrepreneurs enter the market and:

i) the first $n^{\prime \prime} \in\left(0, n^{\prime}\right)$ of these choose the high-quality technology, and raise $\bar{D}$ of debt and $F_{H, i}-\bar{D}$ of equity;

ii) the remaining $n^{\prime}-n^{\prime \prime}>0$ entrepreneurs choose the low-quality technology and finance their fixed costs entirely with debt by borrowing $D_{i}^{*}=F_{L}+\theta n^{\prime}$. Here $n^{\prime \prime}\left(n^{\prime}\right)$ is a decreasing (increasing) function of $\beta$.

In equilibrium, both low-quality and high-quality technology coexist when $\beta<\bar{\beta}$. Entrepreneurs that choose the high-quality technology, $i \leq n^{\prime \prime}$, issue first debt up to debt capacity, and then issue all the equity necessary to cover the fixed costs, $F_{H, i}$. Their number, $n^{\prime \prime}$, is determined by the condition that the marginal entrepreneur is able to obtain financing, that is

$$
\left(\frac{\alpha}{n^{\prime \prime}+\phi\left(n^{\prime}-n^{\prime \prime}\right)}\right)^{2}-\left(F_{H}+\theta n^{\prime \prime}\right)-\beta \eta \geq 0
$$

and by the condition that he prefers to raise $F_{H, n^{\prime \prime}}$, and select the high-quality technology, rather than to raise $F_{L, n^{\prime \prime}}$ and select the low-quality technology, that is

$$
(1-\phi)\left(\frac{\alpha}{n^{\prime \prime}+\phi\left(n^{\prime}-n^{\prime \prime}\right)}\right)^{2}-\left(F_{H}-F_{L}\right)-(1-\mu) \beta \eta \geq 0 .
$$


Entrepreneurs' incentives to choose the high-quality technology rather than the low-quality one can be seen by examining the three terms in (5.2). The first term reflects the fact that the high-quality technology produces superior quality goods with certainty, while the low-quality technology produces superior quality goods only with probability $\phi$. The second term represents the difference in the fixed costs of the two technologies, $F_{H}-F_{L}$. The third term represents a governance cost, and is due to the fact that the high-quality technology can be adopted in equilibrium only if the entrepreneur is financed by equity in the amount of $\eta$ (so that the incentive compatibility condition is satisfied), while the low-quality technology can be financed entirely by debt. Since equity financing generates an efficiency loss, the adoption of the high-quality technology is costly to the entrepreneur and leads to a loss of value equal to $(1-\mu) \beta \eta$.

Entrepreneurs that choose the low-quality technology, that is $i \in\left(n^{\prime \prime}, n^{\prime}\right]$, can finance their fixed cost $F_{L, i}$ entirely by debt. This happens because their investors are not exposed to moral hazard, and the entrepreneurs optimally choose debt to avoid the dissipative cost of equity. The number of entrepreneurs that enter the market with the low-quality technology is determined by the condition that the marginal entrepreneur is just able to raise the fixed cost $F_{L, n^{\prime}}$.

The presence of the low-quality technology limits the ability of entrepreneurs to adopt the high-quality one. From the financing constraint (5.1) it is easy to see that, all else equal, an increase of the number of low-quality firms that enter the market, that is a larger $n^{\prime}$, has the effect of reducing the number of entrepreneurs with high-quality technology that can coexist in equilibrium, $n^{\prime \prime}$. Conversely, a decrease of the number of high-quality firms that enter the market, that is a smaller $n^{\prime \prime}$, has the effect of increasing the number of entrepreneurs with low-quality technology that can be sustained in equilibrium, $n^{\prime}$. Thus, easier access to the capital markets that facilitates entry by entrepreneurs adopting the low-quality technology (for example, by improvements in credit markets, on which the low-quality technology is relatively more dependent) displaces, in equilibrium, the high-quality technology.

An additional implication of Proposition 4 is that the number of firms that choose the highquality technology is lower in economies where the quality of the corporate governance system is of worse quality. This happens because an increase in $\beta$ makes the incentive constraint (5.2) and the financing constraint (5.1) tighter, leading to a lower $n^{\prime \prime}$. Similarly, sectors more exposed to the moral hazard problem, that is, with a greater $\eta$, are characterized by a smaller number of 
firms with high-quality technology. Interestingly, when the quality of the corporate governance system is sufficiently low, it is quite possible that either (5.1) or (5.2) is not satisfied for any $i \leq n^{\prime}$. This implies that the high-quality technology cannot be sustained in equilibrium; we refer to this phenomenon as one of governance crowding out.

Proposition 5 (Governance crowding out): The high-quality technology cannot be sustained in equilibrium, that is, $n^{\prime \prime}=0$, in an industry with moral-hazard $\eta$, if $\beta>\beta^{\prime}$ (where $\beta^{\prime}$ is defined in the Appendix II). Furthermore, $\lim _{\theta \rightarrow 0} \beta^{\prime}=\frac{F_{L}-\phi F_{H}}{\phi \eta}$.

These observations imply that the quality of a country's corporate governance system has an impact on the choices of technology made by firms operating in its jurisdiction and thus on the industrial structure of its economy. ${ }^{26}$ In particular, our model suggests that countries with a low-quality of corporate governance system may not be able to sustain more efficient firms in capital intensive industries that are more exposed to moral hazard, such as, for example, the high-technology and pharmaceutical sectors. Thus, these countries will be at a competitive disadvantage in developing such more advanced sectors. These are new and testable predictions. ${ }^{27}$

\section{Governance and the Structure of Financial Systems}

\subsection{Governance and Bank Financing}

Banks can reduce the agency costs of debt by monitoring firms and thus mitigating the entrepreneur's incentives to take excessive risks (see, for example, Diamond, 1991, among others). Assume now that the economy is endowed also by competitive banks and that, by incurring a fixed monitoring cost, $c_{b}$, a bank can decrease the extent of entrepreneurial moral hazard. The benefit of bank financing is to lower the minimum equity that a firm must maintain from $\eta$ to, say, $\lambda \eta$, thus reducing the agency costs of equity and increasing debt capacity. The monitoring cost is charged up front to the entrepreneur when he borrows from the bank, increasing the cost

\footnotetext{
${ }^{26}$ Note that Proposition 5 implies that when the efficiency differences between technologies become small, $\theta \rightarrow 0$, and when $\phi \rightarrow F_{L} / F_{H}, \beta^{\prime}$ approaches zero. In this case, the high-quality technology is never chosen in equilibrium

${ }^{27}$ In Appendix I, we provide evidence consistent with our model's prediction. Specifically, in Table A1, part c, we show that economies with higher investor protection are also characterized by a better developed hightechnology sector.
} 
of entering a market.

Firms may seek financing either from investors, in the form of publicly traded debt, or equity as before, or by borrowing from a bank. It is easy to see that bank debt is preferable to publicly traded debt when the savings in terms of lower agency cost of equity (due to the lower minimum equity that is necessary with bank financing) is greater than the monitoring cost, $c_{b}$, that is

$$
c_{b}<(1-\mu)(1-\lambda) \beta \eta
$$

Note also that the use of bank debt, by reducing the moral hazard problem, may allow entry of firms that otherwise would not obtain financing and be excluded from the market. By direct examination of the entry condition (3.20), it is easy to see that if

$$
\beta \eta>\lambda \beta \eta+c_{b},
$$

that is, if $c_{b}<(1-\lambda) \beta \eta$, some marginal firms will now be able to raise required capital by using bank financing and enter the market.

These observations have several implications. Since condition (6.1) is more likely to be satisfied when $\beta$ is large, firms operating in countries characterized by bad corporate governance are more likely to be bank financed. This also implies that the financial system in such countries is likely to be dominated by (or to make a greater us of) banks. Similarly, firms in industries characterized by greater moral hazard are more likely to use bank financing rather than publicly traded debt, since (6.1) and (6.2) are more likely to be satisfied when $\eta$ is large. Finally, when (6.1) fails but (6.2) holds, more efficient firms do not benefit from bank financing and are financed by traded debt, while less efficient ones (the marginal firms) use bank financing in order to enter the market - a prediction consistent with the findings in Robb and Robinson (2009). ${ }^{28}$

\subsection{Governance, Financial Innovation and Entry}

Firms' incentives to take excessive risks, that arise from debt financing, can be curbed by the use of convertible securities, such as convertible debt or warrants (see, e.g., Green, 1984). This means that financial innovations, by facilitating firms' ability to raise capital, could lead to

\footnotetext{
${ }^{28}$ Thus, our model provides an explanation for the choice between bank and publicly traded debt different from the one discussed, for example, in Diamond (1991) and Chemmanur and Fulghieri (1994).
} 
more entry, reduce industry's concentration and spur competition. In this section we show that the interaction of the agency costs of equity with the risk shifting problem limits the ability of convertible securities to curb the risk shifting problem. In fact, the use of convertible instruments may exacerbate both the risk shifting problem and the agency cost of equity, and need not generate new entry into an industry.

Proposition 6 (Financial innovation and industry structure): There exists a $\underline{\beta}<1$ such that if $\underline{\beta}<\beta \leq 1$ the high-quality technology is chosen in equilibrium by all firms, the number of firms entering the industry is $n^{*}$, and while the more efficient firms may use convertible debt, the least efficient ones (with indices sufficiently close to $n^{*}$ ) use only straight debt. Furthermore, there exists $\underline{\mu}<1$, such that $\underline{\beta}=0$ for $\mu>\underline{\mu}$.

Proposition 6 implies that when the quality of corporate governance is low (high $\beta$ ), market concentration is not affected by the use of convertible bonds. The effectiveness of convertible debt as a tool to deter insiders from excessive risk taking depends on the fraction of equity owned by the firm's insiders. Remember that in our model entrepreneurs first appropriate a fraction $\beta$ of the cash flow to equity, that is the firm's cash flow net of payments to creditors, and then receive a fraction of the residual cash flow in proportion to the fraction of equity they own. ${ }^{29}$ Conversion of the convertible bonds affects insiders' incentives in two opposing ways. First, conversion removes debt, which increases the cash flow to equity and allows the insiders to appropriate a greater fraction of their firm's cash flow. Therefore, conversion of convertible debt eliminates the disciplinary role of debt. Second, conversion of the bonds requires the firm to issue new shares and dilutes existing shareholders, including the insiders, providing the usual deterrent to excessive risk taking (as in Green 1984). If the first cash flow effect dominates the dilution effect, the presence of convertible debt promotes risk taking.

Whether convertible debt promotes or deters risk taking depends on the level of insiders' equity. More efficient entrepreneurs have large equity stakes in their firms and therefore suffer from the potential dilution due to convertible debt. For these entrepreneurs, convertible debt can be an effective tool to reduce the risk shifting problem, increasing debt capacity and, thus, reducing the agency cost of equity they suffer. In contrast, the most inefficient entrepreneurs

\footnotetext{
${ }^{29}$ Recall also that in our model firms' cash flow can be observed by outsiders (i.e., the bondholders) even if only a fraction $1-\beta$ of the cash flows is contractible.
} 
can enter the market only if they raise large amount of outside financing and, thus, retain very little equity. For these entrepreneurs the cash flow effect dominates the dilution effect when $\beta$ is sufficiently large. Interestingly, for these entrepreneurs, the use of convertible debt affects the risk shifting problem so that it promotes risk taking. This implies that, in equilibrium, entrepreneurs with less inefficient technologies (large $i$ ) do not issue convertible debt and use only straight debt. These observations imply that availability of convertible debt (and other option-like instruments) does not induce any additional entry in countries with poor corporate governance regimes (high $\beta$ ).

\section{The Choice of Governance Systems}

The quality of the corporate governance system and the level of investor protection in an economy need not be fixed, as we have assumed so far, but may be determined endogenously. In this section we examine the incentives to improve the quality of the governance system at the level of individual firms as well as at the level of the overall economy.

\subsection{Governance as a Competitive Tool}

Companies can use the corporate governance system as a competitive tool and choose the quality of their corporate governance as part of their cost minimization efforts (see, for example, Allen and Gale, 2000). In this section we examine the possibility that a firm, by sustaining additional costs, can improve the quality of its own governance system beyond the level determined by its legal environment (i.e., its legal jurisdiction). Examples of this type of firm specific activities include improving corporate disclosures, hiring highly reputable (and, presumably, more expensive) independent directors, or changing corporate charters in ways that protect minority shareholders.

Assume now that the entrepreneur $i$ can, at $t=0$, by exerting a level of effort $e_{i} \geq 0$, reduce the fraction of cash flow to equity that he can appropriate to $\beta\left(1-e_{i}\right)$, but at a cost equal to

$$
C\left(k, e_{i}\right)=\frac{k e_{i}}{1-e_{i}},
$$

where $k \geq 0 .{ }^{30}$ Thus, we can still interpret the parameter $\beta$ as representing the overall quality of

\footnotetext{
${ }^{30}$ Note that this cost function has the attractive properties that the cost is zero if effort is zero, and that
} 
the corporate governance system of the legal jurisdiction where the firm operates. In addition, entrepreneurs can exert effort and improve the quality of the governance system of their firms so as to further reduce the diversion factor to $\beta\left(1-e_{i}\right)$. Propositions 7 and 8 characterize the equilibrium for different values of $k$. In both cases, entry to an industry occurs until the marginal entrepreneur's payoff, net of the costs from improving governance, equals zero.

Proposition 7 (Endogenous governance): If $k \leq k_{1}$ (defined in Appendix II), there exists an equilibrium where the first $n^{* *}$ entrepreneurs enter the market, with $n^{*}<n^{* *}<n^{c}$. In this case, the optimal effort level exerted by each entrepreneur is

$$
e^{* *}=1-\sqrt{\frac{k}{\beta(1-\mu) \eta}},
$$

and the optimal governance that thus emerges in an industry is

$$
\hat{\beta}^{*} \equiv\left(1-e^{* *}\right) \beta=\sqrt{\frac{k \beta}{(1-\mu) \eta}} .
$$

Exerting effort to improve the quality of a firm's governance system reduces the agency cost of equity and allows entrepreneurs to raise more capital in the equity market. Thus, by producing better governance, firms relax their financing constraint, promoting entry. If the cost of producing better governance is not too high, that is, when $k \leq k_{1}$, all entrepreneurs exert the optimal effort, $e^{* *}$. Industry concentration, $n^{* *}$, is determined by the condition that the payoff to the marginal entrant equals the entrepreneurs's cost of producing good governance.

Better corporate governance allows marginal entrepreneurs to raise more capital, leading to additional entry, $n^{* *}>n^{*}$. Thus, the ability of firms to improve their own corporate governance promotes entry, and takes the equilibrium closer to the competitive one, but (since effort is costly) it cannot fully restore the perfectly competitive outcome, $n^{* *}<n^{c}$.

In equilibrium, there is a industry-specific level of corporate governance quality, $\hat{\beta}^{*}$. Direct examination of (7.2) reveals that effort to improve a firm's corporate governance is greatest in industries with high moral hazard (greater $\eta$ ), and in economies characterized by worse corporate governance (greater $\beta$ ). Thus, industries more exposed to moral hazard (greater $\eta$ ) are also characterized in equilibrium by better governance (lower, $\hat{\beta}^{*}$ ). Also, firms located in countries obtaining a "perfect" corporate governance system is prohibitively costly. 
endowed with worse corporate governance regimes are characterized by better corporate governance systems at the firm level. Thus corporate governance at firm level and country level are "substitutes." 31

Following a procedure similar to the one adopted in Section 4, it is easy to verify that better firm level corporate governance is also associated with greater industry concentration, lower leverage, and greater profitability. This implies that entrepreneurs in more concentrated industries have greater incentives to improve the quality of the corporate governance system at their firms. ${ }^{32}$ It also implies a positive correlation between the quality of a firm's corporate governance and its profitability, and a negative correlation between the quality of a firm's governance system and its leverage: firms with better governance are more profitable, have a less concentrated ownership structure and a lower leverage. ${ }^{33}$

If the cost of effort $k$ is relatively large (that is, when $k>k_{1}$ ), some marginal entrepreneurs may not be able to raise the necessary capital to enter the market if they exert the optimal level of effort $e^{* *}$. In this case, marginal entrepreneurs are willing to increase their level of effort beyond $e^{* *}$ to relax the financing constraint and, thus, secure entry in the market.

Proposition 8 (Competitive governance): Let $k>k_{1}$. There exists an equilibrium where the first $\hat{n}$, where $n^{c}>\hat{n}>n^{*}$, entrepreneurs enter the market and the marginal entrepreneur exerts greater effort level, $\hat{e}_{\hat{n}}>e^{* *}$. Furthermore, $\frac{\partial \hat{e}_{i}}{\partial \beta}>0$ and $\frac{\partial \hat{e}_{i}}{\partial \eta}>0$, for all $i \leq \hat{n}$.

Proposition 8 suggests there are heterogenous levels of corporate governance quality also within an industry as entrepreneurs with lower efficiency levels (higher $i$ ) exert a greater level of

\footnotetext{
${ }^{31}$ This is consistent with Klapper and Love (2004), who find that firm-level corporate governance provisions matter more in countries with weak legal environments, which suggests that firms can partially compensate for ineffective laws and enforcement by establishing good corporate governance practices at firm level and providing credible investor protection. In contrast, Aggarwal, Erel, Stulz and Williamson (2009) show that firm and country levels of corporate governance are positively correlated, suggesting a degree of complementarity between firm and country levels of corporate governance. Their result can be reconciled with our model's predictions, if we assume that the cost of producing good governance, $k$, is negatively correlated with country's overall corporate governance quality, as suggested in Doidge, Karoly, and Stulz (2007).

${ }^{32}$ This observation is consistent with Giroud and Mueller (2008), who find that firms in less competitive industries benefit more from good governance.

${ }^{33}$ These predictions are consistent with the findings of Litov (2005), which shows a negative relation between firm's leverage and the quality of its corporate governance.
} 
effort, $\hat{e}_{i}$. This implies that the marginal entrepreneurs, that is, those who need more capital to enter the market, will adopt a better corporate governance system than the more efficient ones. It also implies that firms with greater insiders' ownership are characterized by worse corporate governance. $^{34}$

\subsection{The Politics of Corporate Governance}

Agents within an economy respond differently to changes in their country's corporate governance legislation. For example, investors always prefer (ex-post) better corporate governance as this raises the value of their claims, as in Shleifer and Wolfenson (2002) and Bebchuk and Neeman (2009). Potential entrants in a market, $i \in\left(n^{*}, n^{c}\right]$, always (weakly) prefer better corporate governance, as this may allow them to enter a market and thus exploit a positive profit opportunity.

The quality of the corporate governance system has, instead, an ambiguous impact (in equilibrium) on the firms that are able to enter the market (that is, for $i \in\left[0, n^{*}\right]$ ), and therefore on their controlling shareholders' incentives to lobby in favour (or against) an improvement of legal environment of the economy. Substituting from (3.20) into (3.16), we obtain that entrepreneur $i$ 's equilibrium payoff, $V_{i}^{*}, i \leq n^{*}$, is equal to

$$
V_{i}^{*} \equiv\left(\frac{\alpha}{n^{*}}\right)^{2}-F_{H}-\theta i-\beta(1-\mu) \eta, \quad \text { for } \quad i \leq n^{*} .
$$

From (7.4) it is easy to see that the quality of the governance system has two opposing effects on the these entrepreneurs' welfare. First, corporate governance affects the amount of private benefits, $\beta$, that an entrepreneur can extract from his firm. However, since the extraction of private benefits is inefficient $(\mu<1)$, and securities are fairly priced so that entrepreneurs fully internalize this inefficiency, entrepreneurs suffer in equilibrium from bad governance. This can be seen by noting that, holding $n^{*}$ constant, $V_{i}^{*}$ is decreasing in $\beta$. Second, from (3.8), the

\footnotetext{
${ }^{34}$ These predictions are consistent with Bruno and Claessens (2007), which finds that companies that rely more heavily on external financing have better corporate governance. Durnev and Kim (2005), on the other hand, finds that better firm level corporate governance is associated with greater growth opportunities, greater needs for external financing, and more concentrated cash flow rights. In addition, these relations are stronger in countries with poor investor protection, suggesting again that firms respond to poor legal environments by establishing efficient governance practices at firm level.
} 
quality of corporate governance limits the amount of capital that an entrepreneur can raise, and thus affects entry. In this way, by limiting competition, bad corporate governance increases the equilibrium payoff of the entrepreneurs who can raise financing and enter the market. Thus, for the inframarginal entrepreneurs $\left(i \leq n^{*}\right)$, the net effect of the quality of the corporate governance system is ambiguous. ${ }^{35}$

Proposition 9 (Entrepreneurs' preferences for good governance): For $i \in\left[0, n^{*}\right)$, we have that $\operatorname{sign}\left(\partial V_{i}^{*} / \partial \beta\right)=\operatorname{sign}(\mu-\bar{\mu})$, where

$$
\bar{\mu}=\frac{\theta}{\frac{2 \alpha^{2}}{n^{* 3}}+\theta} .
$$

Furthermore, $\partial^{2} V_{i}^{*} / \partial \beta^{2}>0, \frac{\partial \bar{\mu}}{\partial \beta}<0$ and $\frac{\partial \bar{\mu}}{\partial \alpha}>0$.

Proposition 9 shows that the more efficient entrepreneurs, $i \in\left[0, n^{*}\right)$, benefit from poor corporate governance as long as the extraction of private benefits is not too costly, that is, when $\mu>\bar{\mu}$. If the extraction of private benefits is very inefficient, that is, if $\mu<\bar{\mu}$, the benefits of poor corporate governance, that are due to reduced entry, are not sufficient to compensate entrepreneurs for the efficiency losses of private benefits extraction. Note also that entrepreneurs are more likely to prefer good governance (that is, the threshold level $\bar{\mu}$ is greater) when the size of the product market, $\alpha$, is larger. This happens because in larger markets (for a given level of corporate governance quality), more firms enter the market and the impact of corporate governance on industry concentration is smaller. ${ }^{36}$ These observations imply that entrepreneurs are more likely to prefer good governance either when they operate in larger economies (greater $\alpha$ ), or when the legal system of their economy makes the appropriation of firms' cash flow more difficult and, thus, less efficient (lower $\mu$ ).

It is also interesting to note that entrepreneurs' (equilibrium) utility, $V_{i}^{*}$, is a convex function of the quality of the corporate governance system, $\beta$. This implies that entrepreneurs may

\footnotetext{
${ }^{35}$ Note that the ambiguity of $\beta$ on entrepreneurs' preferences for good governance is the result of the presence of efficiency difference between technologies. To see this, note that if entrepreneurs are endowed with equally efficient technologies (that is, $\theta=0$ ), from (7.4), we have that

$$
V_{i}^{*} \equiv \beta \mu \eta, \quad \text { for } \quad i \leq n^{*},
$$

and all entrepreneurs, in equilibrium, have a strict preference for a corporate governance system of lower quality, as in Perotti and Volpin (2005).

${ }^{36}$ This can be seen by verifying that the elasticity of entry, $\varepsilon\left(n^{*}, \beta \mid \eta\right)$, is decreasing in $\alpha$.
} 
have a preference for "extreme" corporate governance regimes. In other words, entrepreneurs' expected utility may show a local maximum for regimes that have either a very high or a very low-quality corporate governance system, $\beta$. This observation suggests that entrepreneurs operating in economies endowed with a corporate governance system of low-quality may have little or no incentive (locally) to seek, or to lobby for, an improvement of the governance system of their economy. Thus, such economies may be "trapped" in a low-quality governance state. ${ }^{37}$ Conversely, entrepreneurs operating in economies endowed with a corporate governance system of high-quality may have a strong incentive to maintain, or even improve, the quality of the governance system of their economy. This means that countries would "segment" themselves two groups: those with a high-quality of corporate governance and those with low-quality, with relatively little transition from one group to the other. ${ }^{38}$ These results are consistent with the finding that, despite the trend towards increased globalization, there is little evidence of convergence of corporate governance practices over time (see Palepu, Khanna, and Kogan, 2006).

\subsection{Wealth and The Politics of Corporate Governance}

The preference for good corporate governance is also affected by the distribution of wealth in an economy. Until now we have assumed that entrepreneurs have no initial wealth, $W_{0}=0$, and that they must raise all the capital they need from investors. Our model can easily be extend to the case where entrepreneurs are endowed with some wealth, $W_{0}>0$. It is easy to see that if the entrepreneur's wealth is not too large, the resulting equilibrium is the same as that in the basic model, with the exception that $F_{H}^{\prime}=F_{H}-W_{0}$ replaces $F_{H}$ in all equations.

Wealth affects entrepreneurs' preference for good governance in different ways. First, greater wealth may increase the number of entrepreneurs for whom Assumption A2 is violated, and thus $1-\kappa_{i} \geq \mu$. Such firms need to raise less capital from outside investors and, thus, their entrepreneurs have no incentive to divert cash flow to equity, avoiding the efficiency loss from

\footnotetext{
${ }^{37}$ In a similar vein, Mork, Wolfenzon and Yeung (2005) suggest that low income countries appear to be "trapped" in a weak property rights regime with poor governance and economic entrenchment.

${ }^{38}$ This result reflects the endogenous level of debt financing, and thus the endogenous level of efficiency losses from bad corporate governance. In countries with bad corporate governance firms are more debt financed, and thus the efficiency losses from further reducing the level of corporate governce are lower.
} 
cash flow diversion. This means that the controlling shareholders of these firms do not internalize the efficiency gains from improved corporate governance; rather, they always prefer a corporate governance system of poorer quality in order to deter entry, as suggested by Rajan and Zingales (2003). Since wealthy families have a large role of in many countries (see e.g., Morck, Wolfenson and Yeung, 2005), they may form an important interest group shaping countries' corporate governance systems. ${ }^{39}$

Interestingly, however, an increase in wealth makes those entrepreneurs that have an incentive to divert cash flow to themselves, that is, for whom $1-\kappa_{i}<\mu$, more likely to prefer good corporate governance. This happens because greater wealth allows more entrepreneurs to enter a market, reducing the impact of corporate governance on industry concentration. Because of this, greater wealth makes it more likely that the efficiency gains from good governance dominate the benefits from deterring entry to entrepreneurs. This also implies that an exogenous reduction of entrepreneurial wealth in an economy may cause a shift in the entrepreneurs' preference in favor of bad corporate governance. ${ }^{40}$

\section{Financial Market Liberalization, Governance, and Growth}

In this last section, we modify our basic model and examine explicitly the impact of financial market liberalizations on the real economy and thus, ultimately, growth. Liberalizations affect financial markets in several important ways. For example, Bekaert, Harvey and Lundblad (2009) show that equity market liberalizations affect stock market liquidity and equity prices. To capture the effect of financial liberalizations on liquidity, we assume that outside investors require a liquidity premium on their equity investments. In this spirit, we replace constraint (3.8) in

\footnotetext{
${ }^{39}$ Note that in this case wealth concentration promotes further wealth inequality if the more wealthy entrepreneurs are able to successfully lobby for corporate governance of low-quality that deters entry of new entrepreneurs. ${ }^{40}$ This observation is consistent with the finding in Perotti and von Thadden (2006), who argue that the availability of a large middle class wealth seems to have played a large role in shaping the financial systems and corporate governance regimes adopted by various developed countries in Europe and North America. They provide evidence that the countries where the financial holdings of the middle class were devastated by hyperinflation after First World War later moved away from market governance toward bank, family or state control. The countries that avoided this destruction of middle class wealth, on the other hand, coincide with those that we today classify as market oriented economies.
} 
the basic model with

$$
S_{i} \leq \mathbf{E}_{0} \kappa_{i}(1-\delta)(1-\beta) \max \left\{X_{i}^{T}\left(p^{*}, \tau_{i}^{*}\left(B_{i}\right)\right)-B_{i} ; 0\right\},
$$

where the parameter $\delta>0$ represents a "liquidity discount" that investors require in the equity market only. ${ }^{41}$ Inequality (8.1) implies that, due to the liquidity discount, one dollar of cash flow is only worth $1-\delta$ dollars to outside investors. Furthermore, to capture in a simple way the beneficial effect of competition on aggregate output, we now assume total demand in any industry is not constant, but is a decreasing function of the average price level in the industry, that is $\alpha=\alpha^{\prime} / \tilde{p}$, where $\alpha^{\prime}$ is a constant. For ease of exposition, we also set $c=0$.

Proposition 10 (Equity market liberalizations): Let $\xi \equiv \beta+\delta(1-\beta), \mu \geq \mu_{c}^{\circ}$ and $\phi \leq \phi_{c}^{\circ}$ (where $\mu_{c}^{\circ}$ and $\phi_{c}^{\circ}$ are defined in Appendix II). There exists an equilibrium where $n^{\circ}$ firms enter the industry, where

$$
n^{\circ}=\frac{-\left(F_{H}+\eta \xi\right)+\sqrt{\left(F_{H}+\eta \xi\right)^{2}+4 \alpha^{\prime} \theta}}{2 \theta} .
$$

All entrepreneurs choose the high-quality technology and produce output $q_{i}^{\circ}=\sqrt{\frac{\alpha^{\prime}}{n^{\circ}}}$ sold at a price $p_{i}^{\circ}=\sqrt{\frac{\alpha^{\prime}}{n^{\circ}}}$. High-quality industry output, given by $n^{\circ} q^{\circ}=\sqrt{n^{\circ} \alpha^{\prime}}$, is increasing in $n^{\circ}$ and the equilibrium number of firms, $n^{\circ}$, is decreasing in $\delta$. Furthermore, defining the elasticity of entry with respect to $\delta$, as $\varepsilon\left(n^{\circ}, \delta\right) \equiv\left|\frac{\partial n^{\circ}}{\partial \delta} \frac{\delta}{n^{\circ}}\right|$, we have that

$$
\frac{\partial \varepsilon\left(n^{\circ}, \delta\right)}{\partial \alpha^{\prime}}<0, \quad \frac{\partial \varepsilon\left(n^{\circ}, \delta\right)}{\partial \eta}>0, \quad \text { and } \frac{\partial \varepsilon\left(n^{\circ}, \delta\right)}{\partial \beta}<0 .
$$

Proposition 10 shows that equity market liberalizations, associated with a decline in $\delta$, lead to entry of new firms in the economy, which in turn leads to higher output and thus greater growth. Furthermore, the elasticity of entry to the liquidity discount $\delta$ is decreasing in the size of the industry, $\alpha^{\prime}$, and increasing in the level of industry moral hazard, $\eta$. This implies that financial liberalizations (that is, a decrease in $\delta$ ) have greater impact on entry in small industries and in industries more exposed to moral hazard. Finally, the elasticity of entry to $\delta$ is decreasing in $\beta$, which means that the effect of financial market liberalization is more pronounced in economies characterized by high levels of investor protection.

\footnotetext{
${ }^{41}$ We focus here on the effect of financial liberalizations on the equity markets, but our analysis can easily be extended to the case in which the credit market is affected as well.
} 
The prediction that the number of firms increases after equity market liberalizations is consistent with the finding in Rajan and Zingales (1998). This paper shows that the positive effect of equity market liberalization on growth occurs predominantly through an increase in the number of firms. Furthermore, Gupta and Yuan (2009) find that following equity market liberalization, the number of firms increases in industries that are characterized by low entry barriers. Closely related is also Bekaert, Harvey and Lundblatt (2005), which finds that equity market liberalizations increase economic growth, especially in countries characterized by high levels of investor protection.

Financial markets liberalization also affects the industrial structure of the economy. If the low-quality technology is sustainable in equilibrium (as in Section 5.1) financial liberalization, by facilitating the use of equity, promotes the adoption of the high-quality technology versus the low-quality one.

Proposition 11 (Corporate governance, technology choice and liberalization): Let $\phi \in$ $\left(\phi_{c}^{\circ}, F_{L} / F_{H}\right)$ and $\beta<\bar{\beta}^{\circ}$ and $\delta<\bar{\delta}^{\circ}$ (where $\bar{\beta}^{\circ}>0$ and $\bar{\delta}^{\circ}>0$ are defined Appendix II). In equilibrium $n^{\circ \prime}>n^{\circ}$ entrepreneurs enter the market and:

i) the first $n^{\circ^{\prime \prime}} \in\left(0, n^{\circ \prime}\right)$ choose the high-quality technology, and raise $\bar{D}$ of debt and $F_{H, i}-\bar{D}$ of equity;

ii) the remaining $n^{\circ \prime}-n^{\circ^{\prime \prime}}>0$ choose the low-quality technology and finance their fixed costs only with debt by borrowing $D_{i}^{*}=F_{L}+\theta n^{\prime}$. Furthermore, $n^{\circ \prime \prime}\left(n^{\circ \prime}\right)$ is decreasing (increasing) in $\delta$. Total industry output of high-quality goods is decreasing in $\delta$.

Financial market liberalizations promote the adoption of the high-quality technology through two effects. First, by relaxing the financing constraint in the equity market, given by (8.1), liberalizations allow additional marginal entrepreneurs to enter an industry with the high-quality technology. Second, liberalizations reduce the cost of equity for incumbents and make the highquality technology more attractive relative to the low-quality one. This implies that, by promoting high-quality technologies, financial market liberalizations spur productivity and growth. Furthermore, these effects are particularly strong in equity intensive industries, such as the hightechnology sector, and in countries with high levels of investor protection. These predictions help explain the findings in Bekaert, Harvey and Lundblatt (2009), who document increases in 
investment efficiency (and productivity) following financial market liberalizations, especially in countries endowed with more advanced financial system (and, thus, presumably a greater level of investor protection).

Finally, financial market liberalizations affect entrepreneurs' preferences for good governance and their incentives to lobby for a better governance system. Proposition 9 is modified as follows (where $V_{i}^{\circ}$ denotes entrepreneur $i$ 's equilibrium payoff).

Proposition 12 (Financial liberalization and entrepreneurs' preferences for good governance): For $i \in\left[0, n^{\circ}\right)$, we have that $\operatorname{sign}\left(\partial V_{i}^{\circ} / \partial \beta\right)=\operatorname{sign}\left(\mu-\bar{\mu}^{\circ}\right)$, where

$$
\bar{\mu}^{\circ}=\frac{\theta(1-\delta)}{\frac{\alpha}{n^{\circ 2}}+\theta} .
$$

Furthermore: $i) \frac{\partial \bar{\mu}^{\circ}}{\partial \delta}<0$, and ii) $\frac{\partial^{2} V_{i}^{\circ}}{\partial \beta \partial \delta}>0$.

Proposition 12 shows that financial market liberalizations affect entrepreneurs' preferences for good governance in two ways. First, inequality (i) implies that greater liquidity (that is, a smaller $\delta$ ) increases the threshold level $\bar{\mu}^{\circ}$ below which entrepreneurs' payoff increases with better governance, effectively enlarging the set over which entrepreneurs' equilibrium payoffs increases with better corporate governance. Second, inequality (ii) implies that entrepreneurs in countries with better corporate governance, that is, when $\mu<\bar{\mu}^{\circ}$, benefit more from an improvement of the corporate governance system when $\delta$ is lower. ${ }^{42}$ These properties suggests that equity market liberalizations can make entrepreneurs more likely to benefit from, and thus to be in favor of, better corporate governance. This means that entrepreneurs have stronger incentives to lobby for an improvement of the corporate governance of their economies and, thus, that financial liberalizations may be followed also by financial reforms. These results are consistent with the findings that the countries' legislations and institutions promoting investor protection on average improve following financial market liberalizations. For example, Chinn and Ito (2006) find that financial liberalizations spur a country's equity market development (but only if a threshold level of legal development has been attained).$^{43}$

\footnotetext{
${ }^{42}$ This can be seen by noting that part ii) in Proposition 12 implies that $\frac{\partial V_{i}^{\circ}}{\partial \beta}$ becomes more negative when $\delta$ decreases.

${ }^{43}$ In a similar vein, Acemoglu, Johnson, and Robinson (2002) and Acemoglu and Johnson (2005) argue that an institutional environment promoting investment has a first-order effect on long-term growth.
} 


\section{Conclusions}

The main message of our paper is that the quality of the corporate governance system of an economy is an important determinant of its industrial and financial structure. We suggest that the quality of corporate governance affects both industry concentration and the firms' financial structure. We show that countries characterized by poor corporate governance and low levels of investor protection have less competitive economies and have firms with greater leverage and more concentrated equity ownership. We also argue that corporate governance may affect firms' technology choices and in this way economic growth. Our results also suggest that entrepreneurs may locally prefer worse corporate governance in countries already characterized by bad corporate governance, and better corporate governance in countries already endowed with good corporate governance. These results suggest that the different legal systems that support different economic structures may also be favoured by entrepreneurs, providing a reason for why such differences in corporate governance regimes across countries may persist over time. 


\section{References}

[1] Acemoglu, D., S. Johnson and J. Robinson, 2001, The colonial origins of comparative development: An empirical investigation, American Economic Review, 91, 1369-1401.

[2] Acemoglu, D. and S. Johnson, 2005, Unbundling Institutions, Journal of Political Economy 113(5), 949-995.

[3] Aggarwal, R., I. Erel, R. Stulz, and R. Williamson, 2007, Differences in Governance Practices between U.S. and Foreign Firms: Measurement, Causes, and Consequences, ECGI wp 2007.

[4] Aghion, P. and J. Tirole, 1992, An Incomplete Contracts Approach to Financial Contracting, Review of Economic Studies, 59:3, 473-49.

[5] Agrawal, A., 2009, The impact of investor protection law on corporate policy: Evidence from the Blue Sky laws, working paper, NYU Stern, December 2009.

[6] Albuquerque, R. and E. Schroth, 2008, The determinants of the block premium and of private benefits of control, ECGI working paper N. 202/2008.

[7] Alchian, A., 1950, Uncertainty, evolution, and economic theory, Journal of Political Economy, 58, $211-221$.

[8] Allen, F., L. Bartiloro and O. Kowalewski, Does Economic Structure Determine Financial Structure? Mimeo, Wharton School, University of Pennsylvania.

[9] Allen, F. and D. Gale, 2000, Corporate governance and competition, in X. Vives (ed.), Corporate Governance, Cambridge University Press, Cambridge, UK.

[10] Almeida, H. and D. Wolfenzon, 2006, A Theory of Pyramidal Ownership and Family Business Groups, Journal of Finance, 61:6, 2637-2680.

[11] Bebchuk, L. and Z. Neeman, 2009, Investor protection and interest group politics, Forthcoming, Review of Financial Studies. 
[12] Becht, M., P. Bolton, and A. Roell, 2002, Corporate governance and control, ECGI working paper N. 02/2002.

[13] Bekaert, G., C. Harvey and C. Lundblad, 2005, Does Financial Liberalization Spur Economic Growth, Journal of Financial Economics 77, 3-55.

[14] Bekaert, G., C. Harvey and C. Lundblad, 2009, Financial Openness and Productivity, NBER working paper, 14843.

[15] Bolton, P. and D. Scharfstein, 1990, A theory of predation based on agency problems in financial contracting, American Economic Review, 80:1, 93-106.

[16] Booth, L., V. Aivazian, A. Demirguc-Kunt, and V. Maksimovic, 2001, Capital structure in developing countries, Journal of Finance, 56, 87-130.

[17] Brander, J. A., and T. R. Lewis, 1986, Oligopoly and financial structure: The limited liability effect, American Economic Review, 76, 956-970.

[18] Bruno, V. and S. Claessens, 2007, Corporate governance and regulation: Can there be too much of a good thing? Working Paper \#WPS 4140, World Bank Policy Research.

[19] Chemmanur, T. and P. Fulghieri, 1994, Reputation, Renegotiation, and the Choice between Bank Loans and Privately Placed Debt," Review of Financial Studies 7:3, 475-506.

[20] Chinn, M.D. and H. Ito, 2006, What matters for financial development? Capital controls, institutions, and interactions, Journal of Development Economics, 81, 163-192

[21] Demirguc-Kunt, A. and V. Maksimovic, 1998, Law, finance, and firm growth, Journal of Finance, 53, 2107-2137.

[22] Diamond, D. , 1991, Monitoring and Reputation: The Choice Between Bank Loans and Directly Placed Debt," Journal of Political Economy, 99:4, 689-721.

[23] Doidge, C., A. Karolyi, and R. Stulz, 2007, Why do countries matter so much for corporate governance? Journal of Financial Economics, 86, 1-39.

[24] Durnev, A. and H. Kim, 2005, To steal or not to steal: firm attributes, legal environment and valuation, Journal of Finance, 60, 1461-1493. 
[25] Fama, E. and K. French, 2002, Testing trade-off and pecking order predictions about dividends and debt, Review of Financial Studies, 15:1, 1-33.

[26] Fan, J., S. Titman and G. Twite, 2003, An international comparison of capital structure and debt market choice, w.p., June 2003.

[27] Fujita, M., P. Krugman and A. Venables, 1999, The Spatial Economy. Cities, Regions and International trade, Cambridge (Mass.): MIT Press.

[28] Giroud, X. and H. Mueller, 2008, Corporate governance, product market competition, and equity prices, ECGI finance working paper 219/2008, August 2008.

[29] Green, R.C., 1984, Investment incentives, debt and warrants, Journal of Financial Economics, 13:1, 115-136.

[30] Gupta N., and K. Yuan, 2009. On the Growth Effect of Stock Market Liberalizations, Review of Financial Studies, 22: 4715-4752.

[31] Hail, L. and C. Leuz, 2006, International Differences in the Cost of Equity Capital: Do Legal Institutions and Securities Regulation Matter?, Journal of Accounting Research, 44(3), 485531.

[32] Hart, O. and J. Moore, 1995, Debt and seniority: An analysis of the role of hard claims in constraining management. American Economic Review, 85:3, 567-585.

[33] Hart, O. and J. Moore, 1998, Default and renegotiation: A dynamic model of debt, Quarterly Journal of Economics, 113(1), 1-41.

[34] Hyytinen, A., I. Kuosa and T. Takalo, 2002, Law or finance: Evidence from Finland, Bank of Finland discussion papers, 8, 2002.

[35] Jensen, M. C., 1986, The agency costs of free cash flow: Corporate finance and takeovers, American Economic Review, 76: 2, 323-329.

[36] Jensen, M. C. and W. H. Meckling, 1976, Theory of the firm: Managerial behavior, agency costs and ownership structure, Journal of Financial Economics, 3, 305-360. 
[37] John, K. and S. Kedia, 2003, Institutions, Markets and Growth: A Study of Comparative Corporate Governance, wp, NYU.

[38] John, K., L. Litov, and B. Yeung, 2008, Corporate governance and risk taking: Theory and evidence, Journal of Finance, 63:4, 1679-1728,

[39] Karhunen, J., Keloharju, M., 2001, Shareownership in Finland 2000, Finnish Journal of Business Economics 50, 188-226.

[40] Khanna, T., J. Kogan and K. Palepu, 2006, Globalization and Similarities in Corporate Governance: A Cross-Country Analysis, Review of Economics and Statistics, 88: 1 (March), 69-90

[41] Klapper, L. and Love, 2004, Corporate governance, investor protection and performance in emerging markets, Journal of Corporate Finance, 10, 703-728.

[42] Klapper, L., L. Laeven and R. Rajan, 2004, Business environment and firm entry: Evidence from international data, CEPR w.p. N. 4366, April 2004.

[43] La Porta, R., F. Lopez-de-Silanes, A. Shleifer and R. W. Vishny, 1997, Legal determinants of external finance, Journal of Finance, 52:3, 1131-1150.

[44] La Porta, R., F. Lopez-de-Silanes, A. Shleifer and R. W. Vishny, 1998, Law and finance, Journal of Political Economy, 106:6, 1113-1155.

[45] La Porta, R., F. Lopez-de-Silanes, A. Shleifer and R. W. Vishny, 2000, Investor protection and corporate governance, Journal of Financial Economics, 58:1-2, 3-27.

[46] Levine, R., 1997, Financial development and economic growth: Views and agenda, Journal of Economic Literature, 35, 688-726.

[47] Litov, L., 2005, Corporate governance and financing policy: New evidence, working paper, w.p.

[48] MacKay, P., G. M. Phillips, 2005, Is there an optimal industry financial structure? Review of Financial Studies, 18, 1433-1466. 
[49] Maksimovic, V., 1988, Capital structure in a repeated oligopoly, Rand Journal of Economics, 19, 389-407.

[50] Maksimovic, V., and J. Zechner, 1991, Debt, agency costs and industry equilibrium, Journal of Finance, 1619-1645.

[51] Morck, R., D. Wolfenson and B. Yeung, Corporate governance, economic entrenchment and growth, Journal of Economic Literature, September 2005, VXLIII, No 3.

[52] Ottaviano, G., T. Tabuchi and J-F. Thisse, 2002, Agglomeration and Trade Revisited, International Economic Review, 42, 409-435.

[53] Pagano, M. and A. Roell, 1998, The choice of stock ownership structure: Agency costs, monitoring and the decision to go public, Quarterly Journal of Economics, 113:1, 187-226.

[54] Perotti, E. and P. Volpin, 2005, Lobbying on entry, w.p., University of Amsterdam.

[55] Perotti, E.C. and E. L. Von Thadden, 2006,.The Political Economy of Corporate Control. Journal of Political Economy, vol. 114, no. 1, 145-174.

[56] Poitevin, M., 1989, Financial signalling and the deep pocket argument, Rand Journal of Economics, 20:1, 26-40.

[57] Rajan, R. and L. Zingales, 1995, What do we know about capital structure: Some evidence from international data, Journal of Finance, 50, 1-19.

[58] Rajan, R. and L. Zingales, 1998, Financial dependence and growth, American Economic Review, 88, 559-586.

[59] Rajan, R. and L. Zingales, 2003, The great reversals: The politics of financial development in the twentieth century, Journal of Financial Economics, 69:1, 5-50.

[60] Riordan, M., 2003, How do capital markets influence product market competition?, Review of Industrial Organization, 23, 179-191.

[61] Robb, A. and D. Robinson, 2009, The capital structure decision of new firms, w.p., Duke University, 2009. 
[62] Salop, S., 1979, "Monopolistic competition with outside goods," Bell Journal of Economics, $10,141-156$.

[63] Shleifer, A., and D. Wolfenzon, 2002, Investor protection and equity markets, Journal of Financial Economics, 66:1, 3-27.

[64] Shleifer, A. and R. Vishny, 1997, Survey of corporate governance, Journal of Finance, 52:2, 737-783.

[65] Stigler G., 1958, The economies of scale, Journal of Law and Economics, 54-71.

[66] Stulz, R., 1990, Managerial discretion and optimal financing policies, Journal of Financial Economics, 26, 3-27.

[67] Stulz, R., 2005, The limits of financial globalization, Journal of Finance, 60, 1595-1638.

[68] Suominen, M., 2004, Industry Equilibrium with Moral Hazard and Outside Financing: Implications for Market Integration, European Economic Review 48, 1227-1241.

[69] Titman, S. and R. Wessels, 1988, The determinants of capital structure choice, Journal of Finance, 43, no 1, 1-19.

[70] Vives, X., 2000, Corporate governance: Does it matter?, in X. Vives (ed.), Corporate Governance, Cambridge University Press, Cambridge, UK.

[71] Vives, X., 1999, Oligopoly Pricing, The MIT Press, Cambridge, MA, USA.

[72] Williams, J., 1995, Financial and industrial structure with agency, Review of Financial Studies, 8, 431-474. 


\section{Appendix I}

In Table A1 below, we provide empirical evidence on the relationship between the level of investor protection in an economy (a measure of corporate governance) and its industrial and financial structure. The main source of our data is Global Competitiveness Report 2007-2008 by Michael Porter, Xavier Sala-i-Martin and Klaus Schwab. The report provides for a large sample of countries an index of the strenght of investor protection, which was earlier introduced by World Bank (Doing business, 2007). In addition, it contains country level indicators, based on executive surveys, related to the ease of equity financing from local markets and the intensity of local competition. To supplement this data, we have collected from Thomson Financial Database country level data on the percentage of high-tech firms, calculated using equity market capitalizations. Finally, we have obtained from Allen al. (2007) data on the importance of bank debt financing. The table is constructed as follows: we first rank the sample of countries into quartiles based on the levels of investor protection, with I = best and IV = worst. Then, we present the averages and medians for (a) ease of financing from local equity markets; (b) intensity of local competition; (c) percentage of market capitalization of hightech firms; (d) bank credit to market capitalization ratio.

Table A1: Industrial Structure, Finance and Investor Protection

\begin{tabular}{|c|c|c|c|c|c|c|c|c|}
\hline & & \multirow[b]{2}{*}{ sample size } & \multicolumn{4}{|c|}{ Investor protection categories (I best) } & \multirow[b]{2}{*}{ Difference I-IV } & \multirow[b]{2}{*}{ t statistic } \\
\hline & & & 1 & $\|$ & III & IV & & \\
\hline \multicolumn{9}{|c|}{ Ease of financing from local equity markets } \\
\hline Average & & 123 & 5.12 & 4.69 & 4.04 & 3.89 & 1.23 & $5.12^{* * *}$ \\
\hline Median & & & 5.30 & 4.90 & 3.95 & 3.80 & 1.50 & \\
\hline \multicolumn{9}{|c|}{ Intensity of local competition } \\
\hline Average & & 123 & 5.21 & 4.93 & 4.70 & 4.55 & 0.65 & $3.83^{* * *}$ \\
\hline Median & & & 5.40 & 5.10 & 4.60 & 4.50 & 0.90 & \\
\hline \multicolumn{9}{|c|}{ Percentage of market capitalization of high-tech firms } \\
\hline Average & & 60 & $17.7 \%$ & $15.8 \%$ & $10.0 \%$ & $9.2 \%$ & $8.46 \%$ & 1.84 * \\
\hline Median & & & $14.3 \%$ & $10.1 \%$ & $7.5 \%$ & $5.8 \%$ & $8.47 \%$ & \\
\hline \multicolumn{9}{|c|}{ Bank credit to market capitalization ratio } \\
\hline Average & & 84 & 1.85 & 8.62 & 7.01 & 4.90 & $(3.05)$ & $-2.87 * * *$ \\
\hline Median & & & 1.37 & 2.87 & 2.84 & 3.63 & $(2.26)$ & \\
\hline * & Significant at $10 \%$ confidence level & & & & & & & \\
\hline ** & Significant at $5 \%$ confidence level & & & & & & & \\
\hline *** & Significant at $1 \%$ confidence level & & & & & & & \\
\hline
\end{tabular}

Sources: The Global Competitiveness Report 2007-2008 by Porter et. al. (2008), Thomson Datastream, IMF Global Financial Stability Reports and Allen et al. (2007).

1. Investor protection is a measure based on combination of Extent of disclosure index (transparency of transactions), Extent of director liability index (liability of self dealing), and Ease of shareholder suit index (shareholders' ability to sue officers and directors for misconduct). Original source, World Bank, Doing business 2007: How to reform.

Ease of financing through local equity markets measure is based on an executive survey, where the respondents evaluated: Raising money through local equity markets is $(1=$ nearly impossible, $7=$ quite possible for a good company).

3. Intensity of local competition measure is based on an executive survey, where the respondents evaluated: Competition in the local market is $(1=$ limited in most industries and price-cutting is rare, $7=$ intensive in most industries as market leadership changes over time).

4. Definition of high tech-sector was created using the sector descriptions in Thompson Datastream. From 47 industries we selected the industries that belong to our definition of the high tech sector on the basis of the industry average R\&D to Sales-ratios in the US data. High tech sector includes the industries with the highest ratios, and which form roughly $25 \%$ of the number of firms and market capitalization in the US. The firms in the industries selected correspond to $22 \%$ in terms of amount and to $21 \%$ in terms of market value in the US. Our high tech industries are: Alternative Energy, Electronic \& Electrical Equipment, Health Care Equipment \& Service, Industrial Transportation, Software \& Computer Services and Pharmaceuticals \& Biotechnology. Our country figures are the proportions of total market capitalization of the firms belonging to the high tech sector. Our sample is based on more than 46.000 companies for which we obtained the relevant data. In order to minimize the effect of errors in the data and to high tech sector. Our sample is based on more than 46.000 companies for which we obtained the relevant data. In order to minimize the effect of errors in the data and to
eliminate from our sample international firms whose primary listing is outside their home country we required that the indicated primary market matches with the currency in which the data was reported in.

5. Bank Credit / Market capitalization figures are from Allen et al. (2007) and correspond to averages over the period of 1976-2004 


\section{Appendix II}

Proof of Proposition 1. Taking as given $n^{*}$ and $\widetilde{p}^{*}$, the first order condition to (3.1) leads to (3.12). This implies that the equilibrium level of cash flow to a firm $i$ is

$$
X_{i}^{T *}=X^{T *}=\left(p_{i}^{*}-c_{i}\right) q_{i}^{*}=\left(\frac{\alpha}{n^{*}}\right)^{2} .
$$

Substituting the constraints (3.8), (3.9) and (3.10) into (3.7), we obtain that (3.7) can be written as

$$
\begin{gathered}
\max _{B_{i}} \mathbf{E}_{0}\left[X_{i}^{T}\left(p^{*}, \tau_{i}\left(B_{i}\right)\right)-F_{H, i}-\beta(1-\mu) \max \left\{X_{i}^{T}\left(p^{*}, \tau_{i}\left(B_{i}\right)\right)-B_{i} ; 0\right\}\right] \\
\text { s.t. } \quad \tau_{i}\left(B_{i}\right)=\arg \max _{\tau_{i} \in\{H, L\}} \mathbf{E}_{1} X_{i}^{E}\left(p^{*}, \tau_{i}, \kappa_{i}\right) .
\end{gathered}
$$

Since the low-quality technology is not sustainable, in equilibrium only firms that are expected (and have the incentive) to choose the high-quality technology enter. This leads to the incentive compatibility condition (3.18). From (A2) it is easy to see that entrepreneurs first issue debt up to debt capacity $\bar{D}$, after which will issue equity. Given (3.19) the maximum amount of equity that the marginal entrepreneur with cash flow $X^{T *}$ can issue is $S_{n^{*}}^{*}=(1-\beta) \eta$. This implies that $n^{*}$ is determined by

$$
\bar{D}+S_{n^{*}}^{*}=\left(\frac{\alpha}{n^{*}}\right)^{2}-\beta \eta=F_{H, n^{*}}=F_{H}+\theta n^{*},
$$

giving (3.11). Inframarginal entrepreneurs will issue an amount of equity that is just sufficient to cover the fixed cost $F_{H, i}$ giving (3.13). Thus, the fraction of equity sold to outside investors, $\kappa_{i}$, is $S_{i}^{*} /(1-\beta) \eta$, giving (3.15). The payoff to the marginal entrepreneur, who given (A3) sells all his shares to obtain entry, is $\mu \beta \eta$. The payoff to inframarginal entrepreneurs is thus (3.16). Finally, from (3.15), it is easy to see that $1-\kappa_{i}<\mu$ for all $i<n^{*}$ if

$$
\mu \geq \mu_{c} \equiv \frac{\theta n^{*}}{(1-\beta) \eta}
$$

In addition note that no additional entrepreneur with $i>n^{*}$ can enter when $\phi\left(\frac{\alpha}{n^{*}}\right)<F_{L}+\theta n^{*}$, that is, when

$$
\phi \leq \phi_{c} \equiv \frac{F_{L}+\theta n^{*}}{\left(\frac{\alpha}{n^{*}}\right)^{2}} .
$$

The proof is concluded by noting that (A5) implies that

$$
V_{i}=\mu \beta \eta+\theta\left(n^{*}-i\right)>\phi\left(\frac{\alpha}{n^{*}}\right)^{*}-F_{L}-\theta i
$$


and, thus, all entrepreneurs that enter the market prefer to adopt the high-quality technology rather than the low-quality one.

Proof of Proposition 2. The first result follows immediately from Proposition 1 and implicit function differentiation of (3.11), obtaining

$$
\frac{\partial n^{*}}{\partial \beta}=-\frac{\eta}{\frac{2 \alpha^{2}}{n^{* 3}}+\theta}<0
$$

The sign of $\frac{\partial \bar{D}}{\partial \beta}$ follows from direct differentiation of $\bar{D}$ in (3.19) and from (A7). The sign of $\frac{\partial S_{i}^{*}}{\partial \beta}$ follows from the first equality in (3.13) and the previous result that $\frac{\partial \bar{D}}{\partial \beta}>0$. The sign of $\frac{\partial E_{i}^{M *}}{\partial \beta}$ follows from direct differentiation of $E_{i}^{M *}=(1-\beta) \eta$. By differentiation of

$$
\omega_{i}=1-\frac{S_{i}^{*}}{E_{i}^{M *}}=\frac{\theta\left(n^{*}-i\right)}{(1-\beta) \eta}
$$

using (A7), we obtain that

$$
\frac{\partial \omega_{i}^{*}}{\partial \beta}=\theta \frac{\left[\left(\frac{2 \alpha^{2}}{n^{* 3}}+\theta\right)\left(n^{*}-i\right)-(1-\beta) \eta\right]}{\left(\frac{2 \alpha^{2}}{n^{* 3}}+\theta\right)(1-\beta)^{2} \eta}>0
$$

iff $i<i_{c}(\beta, \eta) \equiv n^{*}-\frac{(1-\beta) \eta}{\frac{2 \alpha^{2}}{n^{* 3}+\theta}}$. The inefficiency of low-quality technology implies that $n^{*}>$ $i_{c}(\beta, \eta)>0$. To see this note that $\phi F_{H}<F_{L}$ implies

$$
\frac{2 \alpha^{2}}{n^{* 2}}=2\left(F_{H}+\theta n^{*}+\eta \beta\right)>F_{L}>\frac{\phi\left(F_{H}-F_{L}\right)}{(1-\phi)}=\eta .
$$

Finally, (4.2) is obtained by substituting (A7) into $\varepsilon=\left|\frac{\beta}{n^{*}} \frac{\partial n^{*}}{\partial \beta}\right|$ giving

$$
\varepsilon=\frac{\eta \beta}{\frac{2 \alpha^{2}}{n^{* 2}}+\theta n^{*}}=\frac{\eta \beta}{2\left(F_{H}+\theta n^{*}+\eta \beta\right)+\theta n^{*}}=\frac{1}{\frac{2 F_{H}+3 \theta n^{*}}{\eta \beta}+2},
$$

which is increasing in $\eta$ (since, in the proof of Proposition 3, we will show that $n^{*}$ is decreasing in $\eta$ ).

Proof of Proposition 3. The first result that $\frac{\partial n^{*}}{\partial \eta}<0$ follows immediately from Proposition 1 and implicit function differentiation of (3.11). The sign of $\frac{\partial S_{i}^{*}}{\partial \eta}$ follows from direct differentiation of $S_{i}^{*}$ in (3.13) and the result that $\frac{\partial n^{*}}{\partial \eta}<0$. The sign of $\frac{\partial \bar{D}}{\partial \eta}$ then follows from the first equality in (3.13). The sign of $\frac{\partial E_{i}^{M *}}{\partial \eta}$ follows from direct differentiation of $E_{i}^{M *}=(1-\beta) \eta$. The result that $\frac{\partial \omega_{i}}{\partial \eta}<0$ follows from (A8) and $\frac{\partial n^{*}}{\partial \eta}<0$. 
Proof of Proposition 4. The low-quality technology is sustainable in equilibrium if

$$
\phi>\phi_{c} \equiv \frac{F_{L}+\theta n^{*}}{\left(\frac{\alpha}{n^{*}}\right)^{2}} \Longleftrightarrow \phi\left(\frac{\alpha}{n^{*}}\right)^{2}-F_{L}-\theta n^{*}>0 .
$$

When (A12) holds, if the first $n^{*}$ firms choose the high-quality technology, some additional marginal firms can enter the market by adopting the low-quality technology. Let $\left\{n^{\prime}, n^{\prime \prime}\right\}$ be a candidate equilibrium in which $n^{\prime}$ is the total number of firms in the industry and $n^{\prime \prime} \in$ $\left[0, n^{\prime}\right)$ is the number of firms that choose the high-quality technology. Note first that, in the candidate equilibrium, firms with high-quality technology produce $\tilde{q}_{i}^{*}=\frac{\alpha}{n^{\prime \prime}+\phi\left(n^{\prime}-n^{\prime \prime}\right)}$, and sell their production at a price $\tilde{p}_{i}^{*}=c+\frac{\alpha}{n^{\prime \prime}+\phi\left(n^{\prime}-n^{\prime \prime}\right)}$. This results in cash flow

$$
X_{i}^{T}=\left(\frac{\alpha}{n^{\prime \prime}+\phi\left(n^{\prime}-n^{\prime \prime}\right)}\right)^{2} .
$$

Thus, debt capacity for firms selecting the high-quality technology is now equal to

$$
\bar{D}=\left(\frac{\alpha}{n^{\prime \prime}+\phi\left(n^{\prime}-n^{\prime \prime}\right)}\right)^{2}-\eta
$$

In equilibrium, firms selecting the high-quality technology finance $\bar{D}$ with debt and $F_{H, i}-\bar{D}$ with equity. The remaining $n^{\prime}-n^{\prime \prime}>0$ entrepreneurs who enter the market produce with the low-quality technology, and with probability $\phi$ can produce superior quality goods in the quantity $\tilde{q}_{i}^{*}$. Furthermore, these firms can be financed entirely with debt; thus they borrow $D_{i}^{*}=F_{L}+\theta n^{\prime}$ of debt with a face value $B_{i}=\frac{F_{L}+\theta n^{\prime}}{\phi}$, and repurchase shares for $D_{i}^{*}-F_{L, i}$.

Equilibrium is determined by three conditions: (5.1), (5.2) and the entry condition for the $n^{\prime}$ :th low-quality producer

$$
\phi\left(\frac{\alpha}{n^{\prime \prime}+\phi\left(n^{\prime}-n^{\prime \prime}\right)}\right)^{2}=F_{L}+\theta n^{\prime} .
$$

Furthermore two of the three conditions bind, (A15) and either (5.1) or (5.2). Consider two cases: First, if $\mu \geq \phi$, it is easy to verify that (5.1) implies (5.2) for all $i \geq 0$ if

$$
(1-\phi) \theta n^{\prime \prime}+\beta \eta(\mu-\phi)+F_{L}-\phi F_{H} \geq 0
$$

which holds for all $\beta$. In this case, using (A15) and (5.1) as equalities gives

$$
n^{\prime \prime}=\frac{n^{\prime}}{\phi}-\frac{\phi F_{H}-F_{L}+\phi \beta \eta}{\theta \phi} .
$$


This can be used in (A15) or (5.1) to substitute for either $n^{\prime}$ or $n^{\prime \prime}$ to verify that $n^{\prime \prime}$ is decreasing in $\beta$, while $n^{\prime}$ is increasing in $\beta$. Substituting for $n^{\prime}$ from (A17) into (5.1) and setting $n^{\prime \prime}=0$ gives that $n^{\prime \prime} \geq 0$ if and only if $\beta \leq \beta_{1}$, where $\beta_{1}$ is defined implicitely by

$$
\left(\frac{\alpha \theta}{\phi\left(\phi F_{H}-F_{L}+\phi \beta_{1} \eta\right)}\right)^{2}=F_{H}+\beta_{1} \eta \text {. }
$$

Second, if $\mu<\phi$, (A16) holds for $\beta \leq \beta_{2}$, where $\beta_{2}$ is defined by

$$
\beta_{2}=\frac{F_{L}-\phi F_{H}}{\eta(\phi-\mu)} .
$$

Let $\bar{\beta}=I_{\mu>\phi} \beta_{1}+I_{\mu<\phi} \min \left(\beta_{1}, \beta_{2}\right)$. Note that our assumption that $F_{L}>\phi F_{H}$ implies that $\bar{\beta}>0$.

Proof of Proposition 5: When $\mu \geq \phi$, or when $\mu<\phi$, but $\beta_{1} \leq \beta_{2}$, let $\beta^{\prime}=\bar{\beta}$. When $\mu<\phi$, but $\beta_{1}>\beta_{2}$, (A15) and (5.2) hold as an equality for small enough $n^{\prime \prime}$. Solving for $n^{\prime \prime}$ using (A15) and (5.2) we can verify that $n^{\prime \prime}$ is decreasing in $\beta$. Thus $n^{\prime \prime}=0$ whenever $\beta>\beta_{3}$, where $\beta_{3}$ solves:

$$
(1-\phi)\left(\frac{\alpha \theta}{\phi\left(\frac{\phi F_{H}-F_{L}+(1-\mu) \phi \beta_{3} \eta}{(1-\phi)}\right)}\right)^{2}-\left(F_{H}-F_{L}\right)-(1-\mu) \beta_{3} \eta=0 .
$$

Let: $\beta^{\prime}=I_{\mu>\phi} \beta_{1}+I_{\mu<\phi}\left(I_{\beta_{1}<\beta_{2}} \beta_{1}+I_{\beta_{1}>\beta_{2}} \beta_{3}\right)$. The result regarding the limit when $\theta \rightarrow 0$ follows from (A18) since in the limit $\beta_{1}<\beta_{2}$ when $\mu<\phi$.

Proof of Proposition 6: Convertible debt must be structured so that it is converted if and only if the entrepreneur chooses the risky technology and the output is of high-quality (otherwise it would identical to equity). We will show that if $\beta$ is large enough, convertible debt will not be adopted by the marginal entrepreneur. Note first that with convertible debt the incentive compatibility constraint for entrepreneur $i$ is

$$
\begin{gathered}
\left(\mu \beta+\left(1-\kappa_{i}\right)(1-\beta)\right)\left[\left(\frac{\alpha}{n^{*}}\right)^{2}-B_{i}\right] \geq \\
\phi\left(\mu \beta+\left(1-\kappa_{i}\right)\left(1-\gamma_{i}\right)(1-\beta)\right)\left[\left(\frac{\alpha}{n^{*}}\right)^{2}+F_{H}-F_{L}\right],
\end{gathered}
$$

where $\gamma_{i} \in[0,1]$ is the fraction of shares obtained by convertible debt holders through conversion. The proof is by contradiction: we first assume that the marginal entrepreneur, $n^{*}$, can by selecting convertible debt avoid risk shifting, and then we show that this leads to a contradiction. 
We now show that, for the marginal entrepreneur, the maximal incentives to select the safe technology occur (that is, the incentive compatibility condition (A21) is more easily satisfied) when $\kappa_{i}=0$ and $B_{i}=F_{H, i}$. Note the R.H.S of (A21) is decreasing in $\gamma_{i}$, which means that $\gamma_{i}$ should be as large as possible. To prevent debt holders from converting if the safe technology is chosen (which occurs if $\gamma_{i}^{*}\left(\frac{\alpha}{n^{*}}\right)^{2}(1-\beta)>B_{i}$ ), selecting $\gamma_{i}$ as large as possible (given $B_{i}$ ) gives that

$$
\gamma_{i}^{*}=\min \left(1, \frac{B_{i}}{\left(\frac{\alpha}{n^{*}}\right)^{2}(1-\beta)}\right)>0 .
$$

If convertible debt deters risk taking, firms' financing constraint gives

$$
\kappa_{i}=\max \left(0, \frac{F_{H, i}-B_{i}}{\left[\left(\frac{\alpha}{n^{*}}\right)^{2}-B_{i}\right](1-\beta)}\right) .
$$

First, consider the case that $\kappa_{i}>0$. Substituting for $\kappa_{i}$, the L.H.S. of equation (A21) becomes

$$
[\mu \beta+(1-\beta)]\left(\frac{\alpha}{n^{*}}\right)^{2}-F_{H, i}+B_{i} \beta(1-\mu),
$$

which is an increasing function of $B_{i}$. Consider next the R.H.S. of equation (A21): if $\gamma_{i}^{*}=1$, it is independent of $B_{i}$; if $\gamma_{i}^{*}<1$, from (A22) it can be written as

$$
\begin{gathered}
\phi\left[\mu \beta+\left(1-\kappa_{i}\right)\left(1-\frac{B_{i}}{\left(\frac{\alpha}{n^{*}}\right)^{2}(1-\beta)}\right)(1-\beta)\right]\left[\left(\frac{\alpha}{n^{*}}\right)^{2}+F_{H}-F_{L}\right]= \\
\left(\mu \beta+\frac{\left(1-\kappa_{i}\right)\left(\left(\frac{\alpha}{n^{*}}\right)^{2}(1-\beta)-B_{i}\right)}{\left(\frac{\alpha}{n^{*}}\right)^{2}}\right) \phi\left[\left(\frac{\alpha}{n^{*}}\right)^{2}+F_{H}-F_{L}\right] .
\end{gathered}
$$

Substituting for $\kappa_{i}$ from (A23), we have that

$$
\begin{gathered}
\left(1-\kappa_{i}\right)\left(\left(\frac{\alpha}{n^{*}}\right)^{2}(1-\beta)-B_{i}\right)= \\
=\left(\frac{\alpha}{n^{*}}\right)^{2}(1-\beta)-F_{H, i}+\beta B_{i} \frac{F_{H, i}-B_{i}}{\left(\left(\frac{\alpha}{n^{*}}\right)^{2}-B_{i}\right)(1-\beta)} .
\end{gathered}
$$

This means that, for the marginal entrepreneur, $n^{*}$, (A25) reaches its minimum at $B_{i}=F_{H, i}$. Thus, for $i=n^{*}$, we only have to consider the case where $B_{i}=F_{H, i}$ and $\kappa_{i}=0$. In this case, the incentive compatibility condition (A21) becomes

$$
(\mu \beta+(1-\beta))\left[\left(\frac{\alpha}{n^{*}}\right)^{2}-F_{H, i}\right] \geq \phi\left(\mu \beta+\left(1-\gamma_{i}\right)(1-\beta)\right)\left[\left(\frac{\alpha}{n^{*}}\right)^{2}+F_{H}-F_{L}\right] .
$$


Substituting for $\gamma_{i}^{*}=\min \left(1, \frac{F_{H, i}}{\left(\frac{\alpha}{n^{*}}\right)^{2}(1-\beta)}\right)$ we have that (A21) becomes

$$
\begin{gathered}
(\mu \beta+(1-\beta))\left[\left(\frac{\alpha}{n^{*}}\right)^{2}-F_{H, i}\right] \geq \\
{\left[\mu \beta+(1-\beta) \max \left(0, \frac{\left(\frac{\alpha}{n^{*}}\right)^{2}(1-\beta)-F_{H, i}}{\left(\frac{\alpha}{n^{*}}\right)^{2}(1-\beta)}\right)\right] \phi\left[\left(\frac{\alpha}{n^{*}}\right)^{2}+F_{H}-F_{L}\right] .}
\end{gathered}
$$

We now show that for the $n^{*}$ th firm this condition cannot hold for large $\beta$. First note that for the $n^{*}$ th firm, from (A3), we have that $\left(\frac{\alpha}{n^{*}}\right)^{2}-F_{H, n^{*}}=\beta \eta$. Second, noting that in equilibrium (3.18) and (3.19) hold as equalities, we have

$$
\phi\left[\left(\frac{\alpha}{n^{*}}\right)^{2}+F_{H}-F_{L}\right]=\eta+\phi \bar{D}
$$

Third, note that $\gamma_{n^{*}}=1$ as $F_{H, n^{*}}=\left(\frac{\alpha}{n^{*}}\right)^{2}-\beta \eta>\left(\frac{\alpha}{n^{*}}\right)^{2}(1-\beta)$ given (3.19). Using these results and (A3), the incentive compatibility constraint (A28) for the marginal entrepreneur $n^{*}$ becomes

$$
[\mu \beta+(1-\beta)] \beta \eta \geq \mu \beta \phi\left[\left(\frac{\alpha}{n^{*}}\right)^{2}+F_{H}-F_{L}\right]
$$

or

$$
\beta \leq \underline{\beta} \equiv \max \left\{0, \frac{1-\mu \frac{\phi\left[\left(\frac{\alpha}{n^{*}}\right)^{2}+F_{H}-F_{L}\right]}{\eta}}{1-\mu}\right\}=\max \left\{0, \frac{1-\mu\left(\frac{\eta+\phi \bar{D}}{\eta}\right)}{1-\mu}\right\}<1 .
$$

By continuity of $i$, if $\beta>\underline{\beta}$, (A28) fails also for firms with indices close enough to $n^{*}$. Finally, as $\left(\frac{\eta+\phi \bar{D}}{\eta}\right)>0$, for large enough $\mu$, i.e., $\mu \geq \underline{\mu}, \underline{\beta}=0$. Numerical examples can be used to show that the incentive compatibility constraint (A21) with convertible debt can hold as a strict inequality for more efficient entrepreneurs, when the number of firms is $n^{*}$ and the face value of their convertible debt is $B^{*}$. This implies that those firms can increase their debt, and hence the payoff to the entrepreneur by using convertible debt.

Proof of Proposition 7: Entrepreneurs maximize their expected profits, that is

$$
\max _{B_{i}, \tau_{i}, e_{i}} \mathbf{E}_{0}\left[X_{i}^{T *}\left(\tau_{i}\right)-F_{H, i}-\left(1-e_{i}\right) \beta(1-\mu) \max \left\{X_{i}^{T *}\left(\tau_{i}\right)-B_{i} ; 0\right\}\right]-C\left(k, e_{i}\right)
$$

subject to

$$
\tau_{i}=\arg \max _{\tau_{i} \in\{H, L\}} \mathbf{E}_{1}\left[\mu \beta+\left(1-\kappa_{i}\right)(1-\beta)\right] \max \left\{X_{i}^{T *}\left(\tau_{i}\right)-B_{i} ; 0\right\}
$$


With the given cost function for effort, assuming that A1 and A2 hold, we can rewrite the entrepreneurs objective function, (A32), using our previous results, regarding $B_{i}^{*}$, as:

$$
\max _{e_{i}} \mathbf{E}_{0}\left[\left(\frac{\alpha}{n}\right)^{2}-F_{H}-\theta i-\left(1-e_{i}\right) \beta(1-\mu) \eta-k e\left(1-e_{i}\right)^{-1}\right] .
$$

Let

$$
k_{1} \equiv \frac{(1-2 \mu)^{2}}{1-\mu} \beta \eta
$$

Under our assumption that $k \leq k_{1}$, the first order condition with respect to $e_{i}$ gives the optimal level of effort for all entrepreneurs $i$ :

$$
e_{i}^{* *}=1-\sqrt{\frac{k}{\beta(1-\mu) \eta}} .
$$

Entry to an industry occurs until the marginal entrepreneur's payoff equals zero. Hence, $n^{* *}$ satisfies:

$$
\begin{gathered}
\left(\frac{\alpha}{n^{* *}}\right)^{2}-F_{H}-\theta n^{* *}-\left(1-e_{i}^{* *}\right) \beta(1-\mu) \eta-k e_{i}^{* *}\left(1-e_{i}^{* *}\right)^{-1}= \\
\left(\frac{\alpha}{n^{* *}}\right)^{2}-F_{H}-\theta n^{* *}-2 \sqrt{k \beta(1-\mu) \eta}+k=0,
\end{gathered}
$$

implying that $n^{* *}$ is implicitly determined by

$$
n^{* *}=\frac{\alpha}{\sqrt{F_{H}+\theta n^{* *}+2 \sqrt{k \beta(1-\mu) \eta}-k}}>n^{*} .
$$

To see that $n^{* *}>n^{*}$, note that

$$
\beta \eta>2 \sqrt{k \beta \eta}-k>2 \sqrt{k \beta(1-\mu) \eta}-k
$$

since

$$
\beta \eta-2 \sqrt{k \beta \eta}+k=(\sqrt{k}-\sqrt{\beta \eta})^{2}>0 .
$$

We now need to show that, by exerting effort $e^{* *}$, the marginal entrepreneur is able to raise financing, that is

$$
\left(\frac{\alpha}{n^{* *}}\right)^{2}-F_{H}-\theta n^{* *}-\left(1-e^{* *}\right) \beta \eta \geq 0 .
$$

Using (A37), it is easy to check that (A41) is verified when

$$
k e^{* *}\left(1-e^{* *}\right)^{-1} \geq\left(1-e^{* *}\right) \beta \mu \eta
$$


that is, from (A36), when

$$
k \leq k_{1} \equiv \frac{(1-2 \mu)^{2}}{1-\mu} \beta \eta \leq(1-\mu) \beta \eta
$$

The proof is concluded by noting that A1 holds with the previous definition of $\phi_{c}$ and redefining $\mu_{c}$ as $\mu_{c}=\frac{\theta n^{* *}}{\left(\eta-\sqrt{\frac{k \beta \eta}{(1-\mu)}}\right)}$.

Proof of Proposition 8: In this case, the financing constraint (A41) fails with $n^{* *}$ firms in the market. Hence, less firms enter and at the effort level $e^{* *}$ all entering firms would have strictly positive payoffs. This implies that for some marginal firms (who otherwise would be left out) it pays to exert an amount of effort $\hat{e}_{i}>e^{* *}$ in order to obtain entry. For these firms, $\hat{e}_{i}$ is set sufficiently high to raise the necessary funds to successfully enter the market, that is

$$
\left(\frac{\alpha}{\widehat{n}}\right)^{2}-F_{H}-\theta i-\left(1-\hat{e}_{i}\right) \beta \eta=0 .
$$

The number of firms in this equilibrium, $\hat{n}$, is again determined by the condition that the marginal entrepreneur earns zero expected profits. That is, by

$$
\left(\frac{\alpha}{\hat{n}}\right)^{2}-F_{H}-\theta \hat{n}-\left(1-\hat{e}_{\widehat{n}}\right)(1-\mu) \beta \eta-k \hat{e}_{\widehat{n}}\left(1-\hat{e}_{\widehat{n}}\right)^{-1}=0 .
$$

Substituting (A44) to (A45) gives

$$
\begin{gathered}
\left(1-\hat{e}_{\hat{n}}\right)^{2} \mu \beta \eta-k \hat{e}_{\widehat{n}}=0 \\
\Longrightarrow \\
1+\hat{e}_{\hat{n}}^{2}-\left(2+\frac{k}{\mu \beta \eta}\right) \hat{e}_{\widehat{n}}=0 \\
\text { or } \hat{e}_{\hat{n}}=\frac{1+2 \mu \beta \eta / k-\sqrt{4 \mu \beta \eta / k+1}}{2 \mu \beta \eta / k} \in(0,1) .
\end{gathered}
$$

From (A44) and the first order condition for effort (A36) it is easy to see that for other firms

$$
\hat{e}_{i}=\max \left\{\hat{e}_{\hat{n}}-\frac{\theta(\hat{n}-i)}{\beta \eta}, e^{* *}\right\} .
$$

Taking the derivatives with respect to $\beta$ and $\eta$ gives

$$
\frac{\partial \hat{e}_{\hat{n}}}{\partial \beta}=\left(\sqrt{1+\frac{1}{\left(\frac{k}{\mu \beta \eta}\right)+\left(\frac{k}{2 \mu \beta \eta}\right)^{2}}}-1\right) \frac{k}{2 \mu \eta \beta^{2}}>0,
$$




$$
\frac{\partial \hat{e}_{\hat{n}}}{\partial \eta}=\left(\sqrt{1+\frac{1}{\left(\frac{k}{\mu \beta \eta}\right)+\left(\frac{k}{2 \mu \beta \eta}\right)^{2}}}-1\right) \frac{k}{2 \mu \beta \eta^{2}}>0 .
$$

which implies, given our previous results for $e^{* *}$, and the fact that $\frac{\partial \hat{n}}{\partial \beta}<0$ and $\frac{\partial \hat{n}}{\partial \eta}<0$, as can be verified using (A45), that these derivatives are positive also for other firms.

Proof of proposition 9: For $i<n^{*}$, the derivative of entrepreneur $i$ 's payoff (3.16) with respect to $\beta$ is

$$
\frac{\partial V_{i}^{*}}{\partial \beta}=\mu \eta-\frac{\theta \eta}{\frac{2 \alpha^{2}}{n^{* 3}}+\theta}
$$

implying (7.5). Furthermore, by further differentiation, we obtain

$$
\frac{\partial^{2} V_{i}^{*}}{\partial \beta^{2}}=-\frac{\theta \eta \frac{6 \alpha^{2}}{n^{4}} \frac{\partial n^{*}}{\partial \beta}}{\left(\frac{2 \alpha^{2}}{n^{* 3}}+\theta\right)^{2}}>0 .
$$

Finally, using (3.11) we get

$$
\bar{\mu}=\frac{\theta}{\frac{2 \alpha^{2}}{n^{* 3}}+\theta}=\frac{\theta}{\frac{2}{n^{*}}\left(F_{H}+\theta n^{*}+\beta \eta\right)+\theta}=\frac{\theta}{\frac{2}{n^{*}}\left(F_{H}+\beta \eta\right)+3 \theta}
$$

and

$$
\frac{\partial \bar{\mu}(\beta)}{\partial \alpha}=\frac{\frac{2 \theta}{n^{* 2}}\left(F_{H}+\beta \eta\right) \frac{\partial n}{\partial \alpha}}{\left(\frac{2}{n^{*}}\left(F_{H}+\beta \eta\right)+3 \theta\right)^{2}}>0 .
$$

Proof of Proposition 10: The proof is similar to the proof of Proposition 1, and is only sketched. Taking again $n^{\circ}$ and $\tilde{p}$ as given, entrepreneurs choosing the high-quality technology set $p_{i}=\frac{\alpha^{\prime}}{\tilde{p} n^{\circ}}$, which gives $p_{i}^{\circ}=\sqrt{\frac{\alpha^{\prime}}{n \circ}}$ and $q_{i}^{\circ}=\sqrt{\frac{\alpha^{\prime}}{n^{\circ}}}$; thus, firm profits are now equal to $X^{T \circ}=\frac{\alpha^{\prime}}{n \circ}$. This implies that debt capacity now is $\bar{D}^{\circ}=\frac{\alpha^{\prime}}{n \circ}-\eta$, where $\eta$ is defined as before. Given that the marginal entrepreneur now issues $S_{n^{\circ}}^{\circ}=(1-\delta)(1-\beta) \eta$ of equity, using similar line of reasoning as the one in the proof of Proposition 1, we obtain that $n^{\circ}$ firms producing all with the high-quality technology can enter the market, where $n^{\circ}$ is the positive root of

$$
\theta n^{2}+\left(F_{H}+\eta \xi\right) n-\alpha^{\prime}=0
$$

giving (8.2). Defining $\phi_{c}^{\circ} \equiv \frac{F_{L}+\theta n^{\circ}}{\frac{\alpha^{\prime}}{n^{\circ}}}$ it is easy to show (along the lines in the proof of Proposition 1) that all incumbents prefer to use the high-quality technology, and that there cannot be any 
entry of firms that use the low-quality technology when $\phi \leq \phi_{c}^{\circ}$. Similarly, $1-\kappa_{i} \leq \mu$ for all firms when $\mu \geq \mu_{c}^{\circ} \equiv \frac{\theta n^{\circ}}{(1-\delta)(1-\beta) \eta}$. Direct calculation now gives that

$$
\varepsilon\left(n^{\circ}, \delta\right)=\left|\frac{\frac{\partial n^{\circ}}{\partial \delta}}{\frac{n^{\circ}}{\delta}}\right|=\frac{\eta(1-\beta) \delta}{F_{H}+2 \theta n^{\circ}+\eta \xi}=\frac{(1-\beta) \delta}{\frac{F_{H}+2 \theta n^{\circ}}{\eta}+\xi} .
$$

Thus

$$
\frac{\partial \varepsilon\left(n^{\circ}, \delta\right)}{\partial \alpha^{\prime}}=-\frac{2 \eta \delta \theta(1-\beta) \frac{\partial n^{\circ}}{\partial \alpha^{\prime}}}{\left(F_{H}+2 \theta n^{\circ}+\eta \xi\right)^{2}}<0
$$

and

$$
\frac{\partial \varepsilon\left(n^{\circ}, \delta\right)}{\partial \eta}=\delta(1-\beta) \frac{\frac{F_{H}+2 \theta n^{\circ}}{\eta^{2}}-\frac{2 \theta \frac{\partial n^{\circ}}{\partial \eta}}{\eta}}{\left(\frac{F_{H}+2 \theta n^{\circ}}{\eta}+\xi\right)^{2}}>0,
$$

and

$$
\begin{aligned}
\frac{\partial \varepsilon\left(n^{\circ}, \delta\right)}{\partial \beta} & =-\frac{\eta \delta}{F_{H}+2 \theta n^{\circ}+\eta \xi}-\frac{\eta(1-\beta) \delta\left[2 \theta \frac{\partial n^{\circ}}{\partial \beta}+\eta(1-\delta)\right]}{\left(F_{H}+2 \theta n^{\circ}+\eta \xi\right)^{2}} \\
& =-\frac{\eta \delta\left(F_{H}+2 \theta n^{\circ}+\eta \xi\right)+\eta(1-\beta) \delta\left[2 \theta \frac{\partial n^{\circ}}{\partial \beta}+\eta(1-\delta)\right]}{\left(F_{H}+2 \theta n^{\circ}+\eta \xi\right)^{2}} \\
& =-\frac{\eta \delta\left(F_{H}+2 \theta n^{\circ}+\eta \xi\right)+\eta(1-\beta) \delta\left[\eta(1-\delta)-2 \theta\left(\frac{\eta n^{\circ}(1-\delta)}{F_{H}+2 \theta n^{\circ}+\eta \xi}\right)\right]}{\left(F_{H}+2 \theta n^{\circ}+\eta \xi\right)^{2}} \\
& =-\frac{\eta \delta\left(F_{H}+2 \theta n^{\circ}+\eta \xi\right)+\eta(1-\beta) \delta \eta(1-\delta)\left[\frac{F_{H}+\eta \xi}{F_{H}+2 \theta n^{\circ}+\eta \xi}\right]}{\left(F_{H}+2 \theta n^{\circ}+\eta \xi\right)^{2}}<0 .
\end{aligned}
$$

Proof of Proposition 11: The low-quality technology is sustainable in equilibrium if

$$
\phi>\phi_{c}^{\circ} \equiv \frac{F_{L}+\theta n^{\circ}}{\frac{\alpha^{\prime}}{n^{\circ}}} \Longleftrightarrow \phi \frac{\alpha^{\prime}}{n^{\circ}}-F_{L}-\theta n^{\circ}>0 .
$$

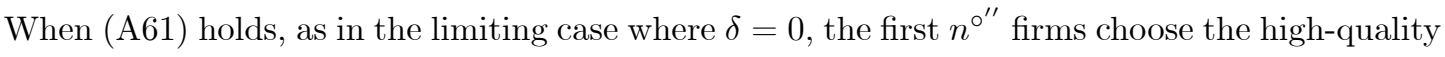
technology and $n^{\circ \prime}-n^{\circ \prime \prime}$ select the low quality technology. Equilibrium is determined by three conditions: The entry condition for the $n^{\mathrm{o}^{\prime \prime}}$ :th entrepreneur,

$$
\left(\frac{\alpha^{\prime}}{n^{\circ \prime \prime}+\phi\left(n^{\circ \prime}-n^{\circ \prime \prime}\right)}\right)-\left(F_{H}+\theta n^{\circ \prime \prime}\right)-\xi \eta \geq 0,
$$

the condition that entrepreneurs prefer to raise $F_{H, n^{\prime \prime}}$, and select the high-quality technology, rather than to raise $F_{L, n^{\prime \prime}}$ and select the low-quality technology, that is

$$
(1-\phi)\left(\frac{\alpha^{\prime}}{n^{0^{\prime \prime}}+\phi\left(n^{\circ \prime}-n^{\circ \prime \prime}\right)}\right)-\left(F_{H}-F_{L}\right)-(\xi-\mu \beta) \eta \geq 0 .
$$


and the entry condition for the $n^{\circ \prime}$ :th low quality producer

$$
\phi\left(\frac{\alpha^{\prime}}{n^{\circ \prime \prime}+\phi\left(n^{\circ \prime}-n^{\circ \prime \prime}\right)}\right)=F_{L}+\theta n^{\circ \prime} .
$$

Furthermore two of the three conditions bind, (A64) and either (A62) or (A63). (A63) is implied by $(\mathrm{A} 62)$ when

$$
(1-\phi) \theta n^{\circ \prime \prime}+(\mu \beta-\phi \xi) \eta+F_{L}-\phi F_{H}>0
$$

This is satisfied when

$$
\frac{(\mu-\phi) \beta \eta+F_{L}-\phi F_{H}}{\phi(1-\beta) \eta} \equiv \bar{\delta}^{\circ} \geq \delta .
$$

$\bar{\delta}^{\circ}>0$ when $(\mu-\phi) \beta \eta+F_{L}-\phi F_{H}>0$.As $F_{L}-\phi F_{H}>0$, there exists $\bar{\beta}^{\circ}>0$ such that this holds for all $\beta<\bar{\beta}^{\circ}$.

In this case, using (A62) and (A64) as equalities gives

$$
n^{\prime \prime}=\frac{n^{\prime}}{\phi}-\frac{\phi F_{H}-F_{L}+\phi \xi \eta}{\theta \phi} .
$$

This can be used in (A62) or (A64) to substitute for either $n^{\circ \prime}$ or $n^{\circ \prime \prime}$ to verify that $n^{\circ \prime \prime}$ is decreasing in $\delta$, while $n^{\circ \prime}$ is increasing in $\delta$. The claim on total production can now be verified as an increase in $\delta$ must lead to a decrease in total output $\alpha^{\prime} / \widetilde{p}$ as $\widetilde{p}=\sqrt{\frac{\alpha^{\prime}}{n^{0^{\prime \prime}}+\phi\left(n^{\circ \prime}-n^{\circ \prime \prime}\right)}}$, which increases by (A64) given the result that $n^{\circ \prime}$ increases in $\delta$.

Proof of Proposition 12: Similarly as before, the payoff to entrepreneur $i \in\left[0, n^{\circ}\right], V_{i}^{\circ}$, is

$$
V_{i}^{\circ}=\mu \beta \eta+\theta\left(n^{\circ}-i\right)
$$

and

$$
\frac{\partial V_{i}^{\circ}}{\partial \beta}=\mu \eta+\theta \frac{\partial n^{\circ}}{\partial \beta}=\mu \eta-\theta\left(\frac{\eta(1-\delta)}{\frac{\alpha^{\prime}}{n^{\circ 2}}+\theta}\right)
$$

Let

$$
\bar{\mu}^{\circ}=\left(\frac{\theta(1-\delta)}{\frac{\alpha^{\prime}}{n^{\circ 2}}+\theta}\right) .
$$

The results (i) and (ii) now follow from $\frac{\partial n^{\circ}}{\partial \delta}<0$ and $\frac{\partial n^{\circ}}{\partial \beta}<0$. 